\title{
Effects of Caffeic Acid and Its Derivatives on Bone: A Systematic Review
}

This article was published in the following Dove Press journal:

Drug Design, Development and Therapy

\author{
Sophia Ogechi Ekeuku (i) \\ Kok-Lun Pang \\ Kok-Yong Chin (i)
}

Department of Pharmacology, Faculty of Medicine, Universiti Kebangsaan Malaysia, Kuala Lumpur, Malaysia
Correspondence: Kok-Yong Chin Department of Pharmacology, Faculty of Medicine, Universiti Kebangsaan Malaysia, Jalan Yaacob Latif, Bandar Tun Razak, 56000 Cheras, Kuala Lumpur, Malaysia Tel +60 3-9|459573

Email chinkokyong@ppukm.ukm.edu.my
Purpose: Caffeic acid is a metabolite of hydroxycinnamate and phenylpropanoid, which are commonly synthesized by all plant species. It is present in various food sources that are known for their antioxidant properties. As an antioxidant, caffeic acid ameliorates reactive oxygen species, which have been reported to cause bone loss. Some studies have highlighted the effects of caffeic acid against bone resorption.

Methods: A systematic review of the literature was conducted to identify relevant studies on the effects of caffeic acid on bone. A comprehensive search was conducted from July to November 2020 using PubMed, Scopus, Cochrane Library and Web of Science databases. Cellular, animal and human studies reporting the effects of caffeic acid, as a single compound, on bone cells or bone were considered.

Results: The literature search found 226 articles on this topic, but only 24 articles met the inclusion criteria and were included in this review. The results showed that caffeic acid supplementation reduced osteoclastogenesis and bone resorption, possibly through its antioxidant potential and increased expression of osteoblast markers. However, some studies showed that caffeic acid did not affect bone resorption in ovariectomized rats and might impair bone mechanical properties in normal rats.

Conclusion: Caffeic acid potentially regulates the bone remodelling process by inhibiting osteoclastogenesis and bone resorption, as well as osteoblast apoptosis. Thus, it has medicinal values against bone diseases.

Keywords: antioxidant, bone, osteoclast, osteoblast, osteoporosis

\section{Introduction}

Bone remodelling is a tightly coupled lifelong process, whereby old bone is removed by osteoclasts (bone resorption) and new bone is formed by osteoblasts (bone formation). ${ }^{1,2}$ Osteocytes, which act as mechanosensors/endocrine cells, and bone lining cells ${ }^{3}$ are also involved in bone remodelling. ${ }^{4}$ Myriad pathophysiological factors affecting bone remodelling have been observed in skeletal diseases such as osteoporosis, arthritis and periodontal disease. ${ }^{5}$ Oxidative stress is one of the pathophysiological factors affecting bone remodelling. Oxidative stress stimulates osteoclast differentiation, thereby enhancing bone resorption. ${ }^{6,7}$ Reactive oxygen species (ROS) stimulate the apoptosis of osteoblasts and osteocytes, thus affecting bone formation. ROS also activate mitogen-activated protein kinases (MAPKs), such as extracellular signal-regulated kinases (ERK1/2), c-Jun$\mathrm{N}$ terminal kinase (JNK) and $\mathrm{p} 38$, and enhance osteoclastogenesis and bone resorption. ${ }^{8-11}$ These phenomena skew the bone remodelling process in favour of bone loss. 
Antioxidants are compounds which reduce free radicals and oxidative stress. ${ }^{12}$ Antioxidants have been reported to promote differentiation of osteoblasts, bone formation and survival of osteocytes, as well as suppressing osteoclast differentiation and activity. ${ }^{8,13-15}$ Some studies associate the age-related reduction in circulating antioxidants to osteoporosis in rats and women. ${ }^{16-18} \mathrm{~A}$ decline in antioxidant levels has been reported to promote bone loss by triggering the tumour necrosis factor-alpha (TNF $\alpha)$ dependent signalling pathway, ${ }^{6}$ while administration of antioxidants, such as vitamin $\mathrm{C}, \mathrm{E}, \mathrm{N}$-acetylcysteine and lipoic acid, have been reported to exert favourable effects in animal models of osteoporosis ${ }^{19-21}$ and individuals with osteoporosis. ${ }^{22-25}$

Caffeic acid (CA) is a metabolite of hydroxycinnamate and phenylpropanoid commonly synthesized by all plant species. It is a polyphenol present in many food sources like coffee, tea, wine, blueberries, apples, cider, honey and propolis. ${ }^{26} \mathrm{CA}$ and its major derivatives including caffeic acid phenethyl ester (CAPE) and caffeic acid 3,4-dihydroxy-phenethyl ester (CADPE) are reported to possess potential antibacterial, antidiabetic, antioxidant, antiinflammatory, antineoplastic and cardioprotective activities (reviewed $i^{27-29}$ ). As a potent antioxidant, CA has been demonstrated to decrease lipoperoxyl radicals (ROO') by donating a hydrogen atom to its corresponding hydroperoxide, which terminates the lipid peroxidation chain reaction. It also inhibits human low-density lipoprotein (LDL) oxidation induced by cupric ions. ${ }^{30}$ Furthermore, it interacts with other compounds, such as $\alpha$ tocopherol, chlorogenic and caftaric acids, to exert more potent antioxidant activity in a variety of different systems. ${ }^{31-33}$ Therefore, the antioxidant activities of CA might protect against the negative effects of oxidative stress on bone cells and the skeletal system. This systematic review aims to summarise the effects of $\mathrm{CA}$ and its derivatives on bone cells and bone in literature.

\section{Materials and Methods}

\section{Literature Review}

A systematic literature search was conducted from July until November 2020 using PubMed, Scopus, Cochrane Library and Web of Science databases to identify studies on the effects of caffeic acid on bone and bone cells including osteoblasts, osteoclasts and osteocytes. The search string used was (1) caffeic acid AND (2) (bone
OR osteoporosis OR osteoblasts OR osteoclasts OR osteocytes).

\section{Selection of Articles}

Studies with the following characteristics were included: (1) original research article with the primary objective of determining the effects of caffeic acid on bone and bone cells; (2) studies using cellular or animal models, or humans; (3) studies administering caffeic acid as a single compound but not in a mixture or food. Articles were excluded if they (1) do not contain original data; (2) use food rich in caffeic acid or mixtures containing caffeic acid. The bibliography of relevant review articles was traced for potential articles missed during database search. The search results were organised using EndNote ${ }^{\mathrm{TM}}$ software (Clarivate Analytics, Philadelphia, USA). Duplicates were identified using EndNote ${ }^{\mathrm{TM}}$ and confirmed by manual checking.

\section{Data Extraction}

Two authors (S.O.E. and K.L.P.) searched the same databases using the search string mentioned and screened the search results. All the articles that did not match the selection criteria were excluded. Next, the articles which used caffeic acid in treating models other than bonerelated diseases were removed. Finally, articles which used caffeic acid in combination with other compounds were also excluded. Any disagreement on the inclusion or exclusion of articles was resolved through discussion among the two authors. The corresponding author (K.Y. C.) had the final decision on articles included if a consensus could not be reached between authors responsible for screening. This systematic review was performed according to the Preferred Reporting Items for Systematic Reviews and Meta-Analyses (PRISMA) guidelines and checklist. ${ }^{34}$ Steps in the selection process, from identification, screening, eligibility to the inclusion of articles, are shown in Figure 1.

\section{Results}

\section{Selection of Articles}

From the literature search, 381 articles were identified, of which 87 were obtained from PubMed, 182 were from Scopus, 3 from Cochrane Library and 109 from Web of Science. A total of 155 duplicate articles were identified and removed. Of the 226 articles screened, 202 articles were excluded based on the selection criteria, whereby 51 


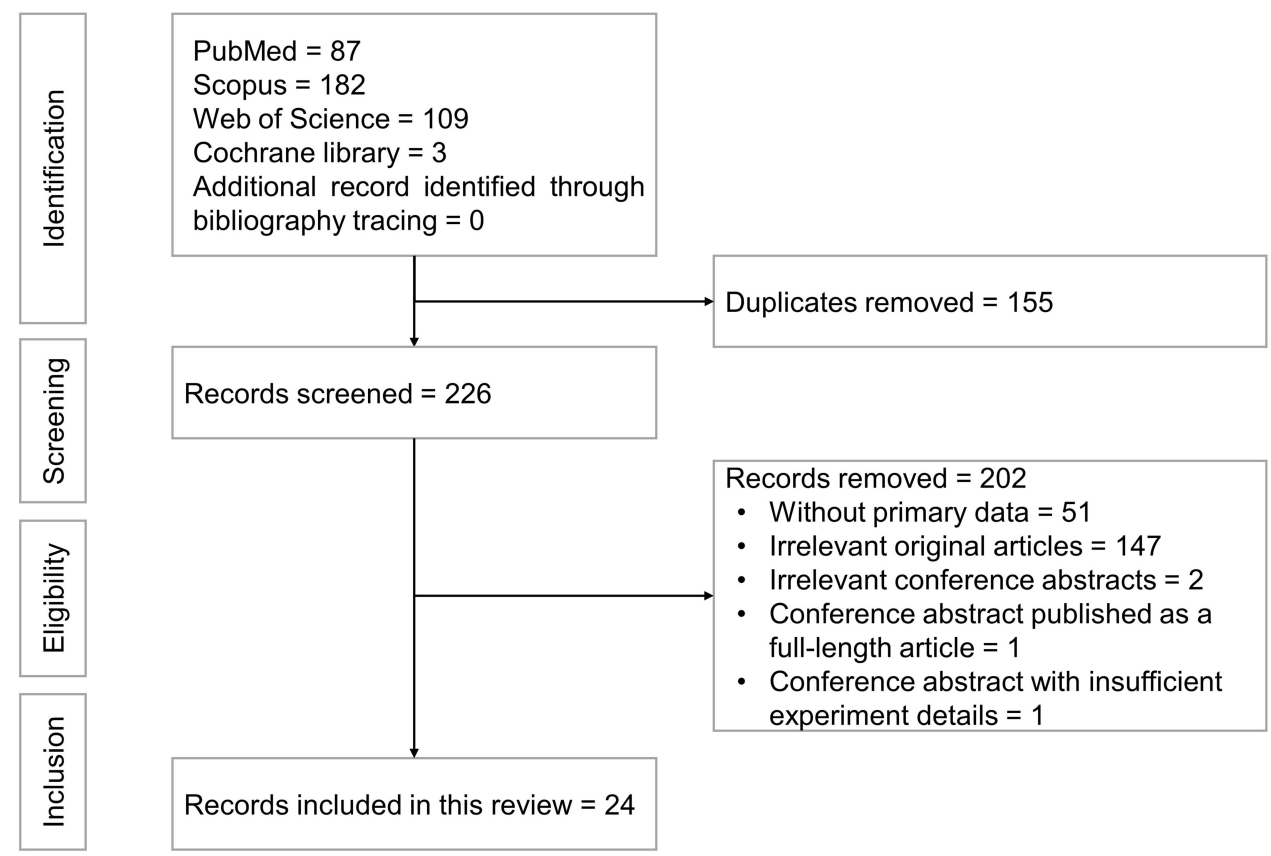

Figure I Flowchart of the article selection process.

articles did not contain primary data (3 book chapters, 2 commentary and 46 review articles), 147 articles and 2 conference abstracts presented topics irrelevant to the current review, a conference abstract had been published as a full-length research article and another conference abstract did not contain sufficient experiment details (Supplementary Material). Finally, 24 articles fulfilling all criteria mentioned were included in the review.

\section{Study Characteristics}

The included studies were published between 2006 and 2020. Seven studies were in vitro experiments using mouse bone marrow macrophages (BMMs), RAW264.7, RAW D and MG63 osteoblast cell lines ${ }^{35-41}$ while 19 studies were in vivo studies using Sprague Dawley/ Sprague Dawley albino rats, Wistar/Wistar albino rats, Balb/c mice, lipopolysaccharide (LPS)-resistant C3H/HEJ mice, C57BL/6J mice and ICR mice. ${ }^{35,38,42-58}$ No human studies on this topic were reported.

Six in vitro studies focused on the effects of $\mathrm{CA}$ on osteoclast differentiation from haematopoietic cells using macrophage colony-stimulating factor (M-CSF), receptor activator of NF-KB (RANK) ligand (RANKL) or TNF$\alpha{ }^{35-39,41}$ while one in vitro study focused on the effect of CA on osteoblasts using MG63 osteoblast cell line. ${ }^{40}$ Four in vitro studies used CA doses between 0.1-5 $\mu \mathrm{M} .^{35,37,38,40}$ Ang et al. $^{36}$ used doses between $0-0.3 \mu \mathrm{M}$ and Sandra et al. ${ }^{41}$ and Sandra and Ketherin ${ }^{39}$ used a dose of $10 \mu \mathrm{g} / \mathrm{mL}(55.5 \mu \mathrm{M})$. The treatment period was 5-7 days for the differentiation of osteoclasts.

For animal studies, Duan et al., ${ }^{55}$ Zawawi et al., ${ }^{58}$ William et al., ${ }^{51} \mathrm{Wu}$ et al., ${ }^{38}$ Zych et al. ${ }^{49}$ and Folwarczna et al. ${ }^{48,52}$ used CA or its derivatives at doses between $0.5-50 \mathrm{mg} / \mathrm{kg}$ via oral or intraperitoneal (i.p.) administration. Ucan et al., ${ }^{57}$ Erdem et al., ${ }^{53}$ Cicek et al., ${ }^{54}$ Yigit et al., ${ }^{45}$ Yildiz et al. ${ }^{50}$ and Tolba et al. ${ }^{56}$ used doses between 10-20 $\mu \mathrm{mol} / \mathrm{kg} /$ day $(2.84-5.69 \mathrm{mg} / \mathrm{kg} /$ day) via $\mathrm{i}$. p. administration. Kizildağ et al. ${ }^{42-44}$ and Kazancioğlu et al. ${ }^{46,47}$ used the dose of $10 \mathrm{mmol} / \mathrm{kg} /$ day $(2.843 \mathrm{~g} / \mathrm{kg} /$ day) for an i.p. administration, Kazancioğlu et al. ${ }^{47}$ employed 50-100 mmol/kg/day (14.22-28.43 g/kg/day) for a localised administration, while Ha et al. ${ }^{35}$ used a collagen sponge soaked with CAPE with the final dose of $250 \mu \mathrm{g} / \mathrm{mouse}$. For oral administration, first-pass effect might affect the enteric absorption of $\mathrm{CA}$ or its derivatives. ${ }^{59}$ For i.p. administration, the injection is commonly performed at the lower left or right quadrant of the abdomen. The peritoneum can absorb the compounds fast and reach systemic circulation with greater bioavailability with fewer handling errors. ${ }^{60}$

The bone-related disease models used included ovariectomy (OVX)- or glucocorticoids (dexamethasone)-induced osteoporosis, polyethylene particle-induced bone defect and osteolysis, electromagnetic force (EMF)-stimulated bone 
loss, osteotomy- or anti-collagen antibody-induced arthritis (CAIA) and rapid maxillary expansion (RME) and LPSinduced periodontitis. The endpoints studied included bone microstructure, histomorphometry, bone remodelling and oxidative status. The effects of $\mathrm{CA}$ and its derivatives on bone remodelling have been summarized in Table 1 .

\section{Evidence from Cell Culture Studies}

Melguizo-Rodríguez et al. reported that 24-hour CA (1 $\mu \mathrm{M})$ incubation increased the number of MG63 osteoblast cells compared with control. ${ }^{40}$ Gene expression studies revealed that $\mathrm{CA}$ increased the expression of osteoblastrelated genes such as bone morphogenetic protein-2 and -7 (BMP-2 and BMP-7), transforming growth factor-beta 1 (TGF- $\beta 1$ ), transforming growth factor-beta receptor 1,2 and 3 (TGF- $\beta R 1, T G F-\beta R 2$ and $T G F-\beta R 3)$ and osteoblastogenesis genes including Runt-related transcription $(R U N X-2)$, alkaline phosphatase $(A L P)$, collagen type 1 $(C O L-I)$, osterix $(O S X)$ and osteocalcin (OSC). ${ }^{40}$ Additionally, pretreatment of CA $(10 \mu \mathrm{g} / \mathrm{mL}$ or $55.5 \mu \mathrm{M})$ on RAW D cells for $2 \mathrm{~h}$ also significantly inhibited the RANKL and TNF $\alpha$-induced osteoclastogenesis with the suppression of p38 MAPK phosphorylation and tartrateresistant acid phosphatase (TRAP)-positive osteoclast-like cells (OCLs) formation. ${ }^{39}$ Similarly, pretreatment of CA $(0.1,1$ and $10 \mu \mathrm{g} / \mathrm{mL}$ or $0.555,5.55$ and $55.5 \mu \mathrm{M})$ on RAW D cells and BMMs for 3 days significantly inhibited the RANKL and TNF $\alpha$-induced osteoclastogenesis and NF- $\kappa \mathrm{B}$ activity in RAW-D cells and RANKL, TNF $\alpha$ and M-CSF-induced osteoclastogenesis in BMMs. ${ }^{41}$

On the other hand, CAPE treatment $(0-0.3 \mu \mathrm{M} ; 5-7$ days) suppressed the formation of TRAP-positive OCLs on RANKL-treated RAW264.7 cells and BMMs. ${ }^{36}$ Apoptosis occurred in CAPE-treated RAW264.7 cells with the disruption of the microtubule network in OCLs. ${ }^{36}$ Similarly, Kwon et al. reported that CAPE treatment $(0.1-5 \mu \mathrm{M})$ for 5 days suppressed OCLs formation from RANKL-stimulated RAW264.7 cells. $^{37}$ Another study by $\mathrm{Ha}$ et al. treating M-CSF and RANKL-stimulated BMMs with CAPE (0-5 $\mu \mathrm{M}$ for 5-7 days) also showed decreased OCLs formation in a concentration-dependent manner. ${ }^{35}$ The amount of TRAP-positive OCLs was decreased upon 0.1 and $0.5 \mu \mathrm{M}$ CAPE treatment by $30 \%$ and $95 \%$ respectively. ${ }^{35}$ No OCL formation was observed upon $1 \mu \mathrm{M}$ CAPE treatment. ${ }^{35}$ The anti-osteoclastogenic activities of CAPE are mainly contributed by its anti-inflammatory and antioxidant properties. Mechanistically, CAPE reduces superoxide anion generation by downregulating the nicotinamide adenine dinucleotide phosphate oxidase 1 (Nox1) expression through the interruption of nuclear factor-kappa $\mathrm{B}(\mathrm{NF}-\kappa \mathrm{B})$ and c-Jun N-terminal kinase (JNK) signalling pathways. ${ }^{37}$ CAPE suppresses RANKL-mediated activation of the NF- $\kappa$ B pathway by downregulating NF- $\mathrm{B}$ p65 subunit expression and its nuclear translocation, ${ }^{37}$ suppressing nuclear factor of activated T cells (NFAT) activities ${ }^{36}$ and degradation of NF- $\kappa B$ inhibitor $(\mathrm{I} \kappa \mathrm{B} \alpha),{ }^{36,37}$ as well as inducing the degradation of IKB kinase (IKK). ${ }^{37} \mathrm{CAPE}$ also suppresses the expression and activation of $\mathrm{JNK}$ and its downstream transcription factors, such as c-Fos and c-Jun, which subsequently interrupt the protein activator-1 (AP-1) complex formation. ${ }^{37}$ Additionally, CAPE suppressed RANKL-induced activation of the Nox 1 by inhibiting the Nox $47^{\text {PHOX }}$ subunit translocation to the cell membrane and downregulation of Rasrelated C3 botulinum toxin substrate 1 (Rac1) expression. ${ }^{37}$

On the other hand, $\mathrm{Wu}$ et al. reported that CADPE (0.1-5 $\mu \mathrm{M}$ for 7 days) also concentration-dependently reduced OCL formation in the M-CSF and RANKLstimulated BMMs and RAW264.7 cells. ${ }^{38}$ Mechanistic and characterisation examination revealed that CADPE suppressed RANKL-induced tumour necrosis factor receptor-associated factor 6 (TRAF6) activation and protein kinase $\mathrm{B}$ (PKB or also known as Akt) and activation of major MAPKs including ERK, JNK and $\mathrm{p} 38 .^{38}$ Subsequently, CADPE suppressed downstream expression of nuclear factor of activated T-cells cytoplasmic 1 (NFATc1), nuclear translocation of c-Fos protein and expression of osteoclastic markers, such as TRAP and cathepsin $\mathrm{K}$, possibly through the non-receptor tyrosine kinase c-Src signalling. ${ }^{38}$ Interestingly, CADPE did not significantly affect the NF-kB signalling pathway and M-CSF-induced proliferation and differentiation of BMMs.

\section{Evidence from Animal Studies}

Supplementation of $\mathrm{CA}$ in animal models of bone loss yielded heterogeneous findings. ${ }^{48,49,52}$ This observation might be attributable to oral administration. Folwarczna et al. reported that $\mathrm{CA}$ ( 5 and $50 \mathrm{mg} / \mathrm{kg}$, by stomach tube for 4 weeks) improved the bone mechanical properties by increasing the width of the trabecular metaphysis of the femur and decreasing the transverse growth in endosteal of the femur in OVX rats. ${ }^{48}$ Folwarczna et al. then demonstrated that CA $(10 \mathrm{mg} / \mathrm{kg} /$ day; oral administration for 4 weeks) could reduce the width of tibial periosteal and endosteal osteoid compared with untreated OVX rats. ${ }^{52}$ However, CA did not promote or reduce the resorption 
Table I Effects of CA and Its Derivatives in Bone Remodelling

\begin{tabular}{|c|c|c|}
\hline Researcher & Study Design & Findings \\
\hline \multicolumn{3}{|c|}{ Cell culture studies } \\
\hline Ang et al. ${ }^{36}$ & $\begin{array}{l}\text { Cell line: RAW264.7 cells, murine BMMs and human OCL cells } \\
\text { Mode of disease induction: RANKL-induced osteoclastogenesis } \\
\text { Treatment: } 0-300 \text { nM of CAPE for } 5-7 \text { days } \\
\text { Negative control: untreated cells } \\
\text { Positive control: n.a. }\end{array}$ & $\begin{array}{l}\downarrow \text { RANKL-induced osteoclastogenesis and TRAP-positive cells } \\
\text { compared with negative control (RAW264.7 and BMMs) } \\
\downarrow \text { RANKL-mediated NF-KB activation, NF-KB p65 nuclear } \\
\text { translocation, IKB } \alpha \text { degradation and NFAT activation compared } \\
\text { with negative control (RAW264.7 and BMMs) } \\
\downarrow \text { bone resorption and } \uparrow \text { apoptosis of CAPE-treated OCL cells }\end{array}$ \\
\hline Ha et al. ${ }^{35}$ & $\begin{array}{l}\text { Cell line: BMMs } \\
\text { Mode of disease induction: M-CSF }(20 \mathrm{ng} / \mathrm{mL}) \text { and RANKL (I } 50 \\
\mathrm{ng} / \mathrm{mL}) \text {-induced osteoclastogenesis } \\
\text { Treatment: } 0-5 \mu \text { M of CAPE for } 5-7 \text { days } \\
\text { Negative control: untreated cells } \\
\text { Positive control: } \text { n.a. }\end{array}$ & 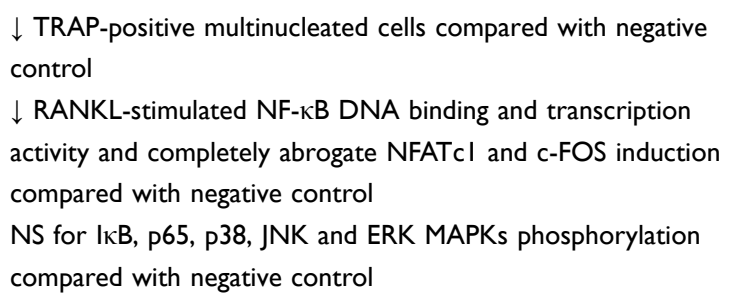 \\
\hline Wu et al. ${ }^{38}$ & $\begin{array}{l}\text { Cell line: Mouse BMMs and RAW264.7 cells } \\
\text { Mode of disease induction: M-CSF }(20 \mathrm{ng} / \mathrm{mL}) \text {-induced } \\
\text { proliferation and differentiation/RANKL ( } 30 \mathrm{ng} / \mathrm{mL} \text { )-induced } \\
\text { osteoclast differentiation } \\
\text { Treatment: } 0.1,0.5,1,2.5,5 \mu \text { M of CADPE for } 7 \text { days (for } \\
\text { BMMs)/3-5 days (for RAW } 264.7 \text { cells) } \\
\text { Negative control: untreated cells } \\
\text { Positive control: n.a. }\end{array}$ & $\begin{array}{l}\text { Non-cytotoxic at } 5 \mu \mathrm{M} \text { in both BMMs and RAW264.7 } \\
\downarrow \text { number of actin ring structure }(2.5-5 \mu \mathrm{M}) \text {, osteoclast } \\
\text { formation and osteoclastogenesis related markers (NFATcl, } \\
\text { TRAP, cathepsin } \mathrm{K} \text {, and c-Src) compared with negative control } \\
\downarrow \text { RANKL-induced } \mathrm{Ca}^{2+} \text { oscillation and TRAF6/c-Src interaction } \\
\downarrow \text { RANKL-induced phosphorylation of ERKI/2, p38, JNK and } \\
\text { Akt } \\
\downarrow \text { RANKL-induced c-Fos protein nuclear translocation and AP-I } \\
\text { activity }\end{array}$ \\
\hline $\begin{array}{l}\text { Sandra } \\
\text { et al. }\end{array}$ & $\begin{array}{l}\text { Cell line: BMMs and RAW-D cells } \\
\text { Mode of disease induction: M-CSF, RANKL and TNF } \alpha \text {-induced } \\
\text { osteoclastogenesis } \\
\text { Treatment: } 0.1, I \text { and } 10 \mu g / m L \text { of caffeic acid for } 3 \text { days } \\
\text { Negative control: untreated cells } \\
\text { Positive control: n.a. }\end{array}$ & $\begin{array}{l}\downarrow \text { RANKL, TNF } \alpha \text { and M-CSF-induced osteoclastogenesis in } \\
\text { BMMs. } \\
\downarrow \text { RANKL and TNF } \alpha \text {-induced osteoclastogenesis in RAW-D } \\
\text { cells. } \\
\downarrow \text { RANKL and TNF } \alpha \text {-induced NF- } K B \text { activity in RAW-D cells }\end{array}$ \\
\hline $\begin{array}{l}\text { Sandra and } \\
\text { Ketherin }{ }^{39}\end{array}$ & $\begin{array}{l}\text { Cell line: RAW-D cells } \\
\text { Mode of disease induction: RANKL and TNF } \alpha \text {-induced } \\
\text { osteoclastogenesis } \\
\text { Treatment: } 10 \mu \mathrm{g} / \mathrm{mL} \text { of caffeic acid for } 2 \text { hours } \\
\text { Negative control: untreated cells } \\
\text { Positive control: n.a. }\end{array}$ & $\begin{array}{l}\downarrow R A N K L \text { and TNF } \alpha \text {-induced osteoclastogenesis and } \\
\text { phosphorylation of p38 MAPK compared with negative control }\end{array}$ \\
\hline $\begin{array}{l}\text { Kwon } \\
\text { et al. }\end{array}$ & $\begin{array}{l}\text { Cell line: RAW } 264.7 \text { cells } \\
\text { Mode of disease induction: RANKL- induced osteoclastogenesis } \\
\text { Treatment: } 0.1, I \text { and } 5 \mu \text { M of CAPE for } 5 \text { days } \\
\text { Negative control: untreated cells } \\
\text { Positive control: n.a. }\end{array}$ & $\begin{array}{l}\downarrow \text { RANKL-induced osteoclast differentiation and bone } \\
\text { resorption compared with negative control } \\
\downarrow \text { generation of superoxide anions with } \downarrow \text { expression of Nox I } \\
\text { and Racl compared with negative control } \\
\downarrow \text { expression and activation of the JNK and the expression of } \\
\text { AP-I activators such as c-Fos and c- Jun compared with negative } \\
\text { control } \\
\downarrow \text { expression and nuclear translocation of NF- } \mathrm{KB} \text { p } 65 \text { and the } \\
\text { activation of IКB } \alpha \text { and IKK } \beta\end{array}$ \\
\hline
\end{tabular}

(Continued) 
Table I (Continued).

\begin{tabular}{|c|c|c|}
\hline Researcher & Study Design & Findings \\
\hline $\begin{array}{l}\text { Melguizo- } \\
\text { Rodríguez. } \\
\text { et al. }\end{array}$ & $\begin{array}{l}\text { Cell line: MG63 osteoblast cell line Mode of disease induction: } \\
\text { No disease } \\
\text { Treatment: I } \mu M \text { of CA for } 24 \text { hours } \\
\text { Negative control: untreated cells } \\
\text { Positive control: } n \text {.a. }\end{array}$ & $\begin{array}{l}\uparrow \text { gene expression of osteoblast-related markers (BMP-2/BMP-7, } \\
\text { TGF- } \beta I, T G F-\beta R I, T G F-\beta R 2 \text { and TGF- } \beta R 3 \text { ) and osteoblastogenesis } \\
\text { genes (RUNX-2, ALP, COL-I, OSX and OSC) } \\
\uparrow R A N K L \text { expression and } \downarrow \text { OPG expression }\end{array}$ \\
\hline \multicolumn{3}{|c|}{ Animal studies } \\
\hline Yildiz et al. ${ }^{50}$ & $\begin{array}{l}\text { Animals: } 48 \text { Sprague Dawley rats ( } 7 \text { weeks old) } \\
\text { Mode of disease induction: } 900-\mathrm{MHz} \text { and } 1800-\mathrm{MHz} \text { EMF for } 30 \\
\text { mins/day for } 5 \text { days/week for } 28 \text { days. } \\
\text { Treatment: } 10 \mu \mathrm{mL} / \mathrm{kg} / \text { day CAPE for } 28 \text { days (i.p administration) } \\
\text { Normal control: no treatment } \\
\text { Positive control: } \text { n.a. }\end{array}$ & $\uparrow$ spine and femur BMD compared with negative control \\
\hline Cicek et al. ${ }^{54}$ & $\begin{array}{l}\text { Animals: } 48 \text { Sprague Dawley rats }(7 \text { weeks old) } \\
\text { Mode of disease induction: GSM 900-MHz, } 2 \text { W EMF and GSM } \\
\text { I800-MHz, I.5 W EMF for } 30 \mathrm{~min} / \text { day for } 5 \text { days/week for } 28 \\
\text { days. } \\
\text { Treatment: } 0.569 \mathrm{mg} \text { CAPE }(10 \mu \mathrm{mol} / \mathrm{kg} / \text { day }) \text { for } 28 \text { days (i.p. } \\
\text { administration) } \\
\text { Normal control: no treatment } \\
\text { Positive control: n.a. }\end{array}$ & $\begin{array}{l}\uparrow \text { breaking force, bending strength and total fracture energy } \\
\text { compared with negative control }\end{array}$ \\
\hline Zych et al. ${ }^{49}$ & $\begin{array}{l}\text { Animals: } 40 \text { female Wistar Cmd:(WI) WU rats (I90-220g; } 3 \\
\text { months old) } \\
\text { Mode of disease induction: Normal rats (no disease) } \\
\text { Treatment: } 10 \mathrm{mg} / \mathrm{kg} / \text { day of CAPE for } 4 \text { weeks (oral } \\
\text { administration) } \\
\text { Normal control: no treatment } \\
\text { Positive control: } \text { n.a. }\end{array}$ & $\begin{array}{l}\downarrow \text { load of fracture at femoral neck compared with control group } \\
\downarrow \text { width of periosteal osteoid in tibia compared with control } \\
\text { group } \\
\downarrow \text { width of epiphysis and metaphysis trabecular in femur } \\
\text { compared with control group }\end{array}$ \\
\hline $\begin{array}{l}\text { Folwarczna } \\
\text { et al. }\end{array}$ & $\begin{array}{l}\text { Animals: } 48 \text { female Wistar Cmd:(WI) WU rats ( } 12 \text { weeks old) } \\
\text { Mode of disease induction: OVX-induced osteoporosis } \\
\text { Treatment: } 10 \mathrm{mg} / \mathrm{kg} / \text { day of CAPE for } 4 \text { weeks (oral } \\
\text { administration) after } 7 \text { days of OVX operation } \\
\text { Normal control: Sham-operated rats with no treatment } \\
\text { Positive control: } 0.2 \mathrm{mg} / \mathrm{kg} \text { of estradiol }\end{array}$ & $\begin{array}{l}\downarrow \text { bone mass and bone mineral mass compared with negative } \\
\text { control } \\
\downarrow \text { bone mass/body mass ratio and bone mineral mass/body mass } \\
\text { ratio } \\
\downarrow \text { width of tibial periosteal and endosteal osteoid }\end{array}$ \\
\hline Ha et al. ${ }^{35}$ & $\begin{array}{l}\text { Animals: I } 5 \text { Male ICR mice ( } 5 \text { weeks old) } \\
\text { Mode of disease induction: RANKL-induced osteoclastogenesis } \\
\text { in mouse calvariae (Collagen sponge implant) } \\
\text { Treatment: } 250 \mu \mathrm{g} \text { CAPE for } 5 \text { days (along with the sponge } \\
\text { implant) } \\
\text { Normal control: Collagen sponge soaked with vehicle } \\
\text { Positive control: n.a. }\end{array}$ & $\begin{array}{l}\downarrow \text { TRAP-stained area under gross examination and image } \\
\text { analysis }\end{array}$ \\
\hline Wu et al. ${ }^{38}$ & $\begin{array}{l}\text { Animals: } 18 \text { mice (unknown strain) } \\
\text { Mode of disease induction: OVX-induced bone loss } \\
\text { Treatment: } 10 \mathrm{mg} / \mathrm{kg} \text { of CADPE every } 2 \text { days for } 3 \text { months (i.p. } \\
\text { administration), starting from } 7 \text { days after OVX } \\
\text { Normal control: Sham-operated mice } \\
\text { Positive control: } n \text {.a. }\end{array}$ & $\begin{array}{l}\uparrow \mathrm{BV} / \mathrm{TV} \text { and Tb.N compared with negative control } \\
\downarrow \text { Tb.Sp. Oc.S/BS, ES/BS, and N.Oc/B.Pm compared with negative } \\
\text { control } \\
\downarrow \text { TRAP5b and CTX-I compared with negative control }\end{array}$ \\
\hline
\end{tabular}

(Continued) 
Table I (Continued).

\begin{tabular}{|c|c|c|}
\hline Researcher & Study Design & Findings \\
\hline Uçan et al. ${ }^{57}$ & $\begin{array}{l}\text { Animals: } 63 \text { male Sprague Dawley rats ( } 7 \text { weeks old; } 280-490 \mathrm{~g} \text { ) } \\
\text { Mode of disease induction: cranial critical size bone defect } \\
\text { Treatment: } 10 \mu \mathrm{mol} / \mathrm{kg} / \text { day of CAPE for } 30 \text { days (i.p } \\
\text { administration) } \\
\text { Normal control: critical size cranial model with no treatment } \\
\text { Positive control: n.a. }\end{array}$ & $\uparrow$ cranial bone healing level compared with negative control \\
\hline Duan et al. ${ }^{55}$ & $\begin{array}{l}\text { Animals: } 18 \mathrm{C} 57 \mathrm{BL} / 6 \mathrm{~J} \text { female mice (12 weeks old) } \\
\text { Mode of disease induction: OVX-induced osteoporosis } \\
\text { Treatment: } 0.5 \mathrm{mg} / \mathrm{kg} \text { CAPE (in DMSO) twice a week for } 4 \\
\text { weeks (i.p. administration) right after OVX. } \\
\text { Normal control: Sham-operated mice with PBS and DMSO (i.p. } \\
\text { administration) } \\
\text { Positive control: n.a. }\end{array}$ & $\begin{array}{l}\uparrow \mathrm{BV} / \mathrm{TV} \text { and Tb.N compared with negative control } \\
\downarrow \mathrm{N} . \mathrm{Oc} / \mathrm{B} . \mathrm{Pm} \text { compared with negative control }\end{array}$ \\
\hline $\begin{array}{l}\text { Erdem } \\
\text { et } \text { al. }^{53}\end{array}$ & $\begin{array}{l}\text { Animals: } 39 \text { adult male Wistar albino rats }(350-400 \mathrm{~g} \text { ) } \\
\text { Mode of disease induction: Unilateral femoral lengthening } \\
\text { (extension) osteotomy } \\
\text { Treatment: } 10 \mu \mathrm{mol} / \mathrm{kg} \text { CAPE for } 22 \text { days (i.p administration) } \\
\text { Negative control: Rats with lengthening osteotomy with } 1 \% \\
\text { alcohol in physiological saline ( } 5 \mathrm{~mL} / \mathrm{kg} / \text { day via i.p injection) } \\
\text { Positive control: n.a. }\end{array}$ & $\begin{array}{l}\uparrow \text { maximum torsional fracture momentum and degree of rigidity } \\
\text { compared with negative control }\end{array}$ \\
\hline $\begin{array}{l}\text { Kazancioglu } \\
\text { et al. }{ }^{46}\end{array}$ & $\begin{array}{l}\text { Animals: } 32 \text { male Wistar rats (3-months; } 300-330 \text { g) } \\
\text { Mode of disease induction: Surgical-induced calvarial defects } \\
\text { ( } 5 \mathrm{~mm} \text { diameter) which grafted with gelatin sponge and closed } \\
\text { with titanium barriers } \\
\text { Treatment: Pre-mixes of } 50 \text { and } 100 \mathrm{mmol} / \mathrm{kg} \text { CAPE solutions } \\
\text { with the gelatin sponges (localised administration) for } 28 \text { days } \\
\text { or CAPE ( } 10 \mathrm{mmol} / \mathrm{kg} / \text { day) injected for } 28 \text { days (systemic i.p. } \\
\text { administration). } \\
\text { Negative control: Equal volume of isotonic saline solution (i.p. } \\
\text { injection) with the use of saline solution-mixed gelatin sponge } \\
\text { Positive control: n.a. }\end{array}$ & $\begin{array}{l}\uparrow \text { total new bone areas for systemic CAPE } \\
\text { NS between localised CAPE groups and control }\end{array}$ \\
\hline $\begin{array}{l}\text { Zawawi } \\
\text { et al. } .^{58}\end{array}$ & $\begin{array}{l}\text { Animals: } 22 \text { LPS-resistant female } \mathrm{C} 3 \mathrm{H} / \mathrm{HEJ} \text { mice }(6-8 \text { weeks old) } \\
\text { Mode of disease induction: murine polyethylene }(\mathrm{PE}) \text { particle- } \\
\text { induced osteolysis model }\left(2.82 \times 10^{9} \text { particles } / \mathrm{mL}\right) \\
\text { Treatment: I mg/kg/day of CAPE at days } 0,4,7 \text { and } 10 \\
\text { (subcutaneous administration) } \\
\text { Negative control: PBS with } 0.04 \% \text { DMSO } \\
\text { Positive control: } n . a \text {. }\end{array}$ & $\begin{array}{l}\downarrow \text { calvarial osteolysis, surface bone resorption and TRAP- } \\
\text { positive cells compared with negative control } \\
\uparrow \mathrm{BV} \text { compared with negative control } \\
\leftrightarrow \mathrm{CTX}-\mathrm{I} \text { and OSCAR levels compared with negative control }\end{array}$ \\
\hline $\begin{array}{l}\text { Folwarczna } \\
\text { et } \text { al. }^{48}\end{array}$ & $\begin{array}{l}\text { Animals: } 81-90 \text { female Wistar rats ( } 15-17 \text { weeks old) } \\
\text { Mode of disease induction: OVX-induced osteoporosis } \\
\text { Treatment: } 5 \text { and } 50 \mathrm{mg} / \mathrm{kg} / \text { day of CA for } 4 \text { weeks (oral } \\
\text { administration), started } 7-8 \text { days after OVX } \\
\text { Negative control: no treatment } \\
\text { Positive control: } 0.2 \mathrm{mg} / \mathrm{kg} \text { of oestradiol }\end{array}$ & $\begin{array}{l}\downarrow \text { transverse bone growth of endosteal in femur compared with } \\
\text { negative control } \\
\uparrow \text { width of trabeculae metaphysis in femur compared with } \\
\text { negative control }\end{array}$ \\
\hline
\end{tabular}

(Continued) 
Table I (Continued).

\begin{tabular}{|c|c|c|}
\hline Researcher & Study Design & Findings \\
\hline $\begin{array}{l}\text { Kazancioglu } \\
\text { et al. }{ }^{47}\end{array}$ & $\begin{array}{l}\text { Animals: } 203 \text {-month-old male Sprague Dawley rats ( } 222.76 \\
\pm 18.44 \mathrm{~g}) \\
\text { Mode of disease induction: RME-induced new bone formation in } \\
\text { rat midpalatal suture } \\
\text { Treatment: } 10 \mathrm{mmol} / \mathrm{kg} / \text { day of CAPE for } 20 \text { days (i.p. } \\
\text { administration) } \\
\text { Negative control: rats with RME but no treatment } \\
\text { Positive control: } n \text {.a. }\end{array}$ & $\begin{array}{l}\uparrow \text { new bone formation in rat midpalatal suture after RME upon } \\
\text { histomorphometric analysis }\end{array}$ \\
\hline Tolba et al. ${ }^{56}$ & $\begin{array}{l}\text { Animals: } 30 \text { male Sprague Dawley rats }(200-250 \mathrm{~g}) \\
\text { Mode of disease induction: glucocorticoid (dexamethasone)- } \\
\text { induced osteoporosis by intramuscular injection of } \\
\text { dexamethasone disodium phosphate }(7 \mathrm{mg} / \mathrm{kg} \text { ) once per week } \\
\text { for } 5 \text { weeks } \\
\text { Treatment: } 10 \text { and } \\
20 \mu \mathrm{mol} / \mathrm{kg} \text { of CAPE for } 4 \text { weeks (i.p. administration), started } \\
\text { a week after the dexamethasone injection } \\
\text { Negative control: no treatment } \\
\text { Positive control: n.a. }\end{array}$ & $\begin{array}{l}\uparrow \text { femur weight and length compared with negative control } \\
\uparrow \text { alkaline phosphatase and } \downarrow \text { acid phosphatase and TRAP } \\
\text { activity compared with negative control } \\
\downarrow \text { MDA and } \uparrow \text { GSH and SOD in bone tissue compared with } \\
\text { negative control } \\
\downarrow \text { caspase- } 3 \text { activity compared with negative control } \\
\uparrow \text { Runx } 2 \text { and } \downarrow \text { RANKL/OPG ratio compared with negative } \\
\text { control } \\
\downarrow \text { Akt activation compared with negative control }\end{array}$ \\
\hline $\begin{array}{l}\text { Williams } \\
\text { et al. }{ }^{51}\end{array}$ & $\begin{array}{l}\text { Animals: } 32 \text { Balb/c mice ( } 6-8 \text { weeks old) } \\
\text { Mode of disease induction: CAIA induction by intravenous } \\
\text { injection of } 150 \mu \mathrm{L} \text { of a cocktail of anti-type II collagen } \\
\text { monoclonal antibodies on day I, followed by } 20 \mu \mathrm{L} \text { LPS } \\
\text { on day 3) } \\
\text { Treatment: } 200 \mu \mathrm{L} \text { of CAPE (I mg/kg) in } 0.4 \% \text { DMSO on days } 3 \text {, } \\
7 \text { and } 10 \text { (subcutaneous administration) } \\
\text { Normal control: PBS and PBS with } 0.4 \% \text { DMSO } \\
\text { Negative control: PBS and PBS in } 0.4 \% \text { DMSO } \\
\text { Positive control: n.a. }\end{array}$ & $\begin{array}{l}\uparrow \text { paw inflammation compared with normal control, marked by } \\
\uparrow \text { paw score, paw volume, tissue swelling, cartilage and bone } \\
\text { degradation and } \text { TRAP }^{+} \text {cells on bone surface and soft tissues } \\
\text { compared with normal control (NS compared with negative } \\
\text { control) } \\
\downarrow \text { colon toxicity score and percentage of cavitated colon goblet } \\
\text { cells per cyst compared with negative control } \\
\text { NS for BV, and BV change to baseline, CTX-I and C-reactive } \\
\text { protein levels compared with negative control }\end{array}$ \\
\hline Yiğit et al. ${ }^{45}$ & $\begin{array}{l}\text { Animals: } 48 \text { Wistar albino rats }(200 \pm 20 \mathrm{~g}) \\
\text { Mode of disease induction: Ligature-induced periodontitis by } \\
\text { placing a sterile } 3-0 \text { silk ligatures in the subgingival position } \\
\text { around the maxillary } 2 \text { nd molars for } 14 \text { days } \\
\text { Treatment: i.p. administration of } 10 \mu \mathrm{mol} / \mathrm{kg} / \text { day CAPE during } \\
\text { the } 14 \text {-day induction } \\
\text { Normal control: Rats without the subgingival ligature placement } \\
\text { Positive control: Periodontitis rats with low-dose doxycycline } \\
(10 \mathrm{mg} / \mathrm{kg} / \mathrm{day}) \text { via oral gavage }\end{array}$ & $\begin{array}{l}\downarrow \text { articular bone loss, histopathological scores and severity of } \\
\text { periodontal inflammation with significantly lesser PMNLs } \\
\text { infiltration in junctional epithelium and connective tissues } \\
\text { compared with positive control } \\
\downarrow \text { periodontitis-upregulated IL-I } \beta \text {, IL-6, IL-I0, TNF } \alpha \text {, MDA levels } \\
\text { and percentage of gingival apoptosis (near or lower than normal } \\
\text { control) } \\
\uparrow \text { periodontitis-downregulated GSH and GPx (higher than } \\
\text { normal control) }\end{array}$ \\
\hline $\begin{array}{l}\text { Kizildag } \\
\text { et al. }{ }^{42}\end{array}$ & $\begin{array}{l}\text { Animals: } 40 \text { male Sprague Dawley albino rats (I2-week old and } \\
\text { weight } 220-250 \mathrm{~g} \text { ) } \\
\text { Mode of disease induction: A single dose of STZ ( } 60 \mathrm{mg} / \mathrm{kg} \text { ) was } \\
\text { injected via i.p. to induce diabetes. A I0 } \mu \mathrm{L} \text { of LPS (I mg/mL) } \\
\text { was injected into the vestibular gingival sites between the right } \\
\text { first and second maxillary molars to induce periodontitis. } \\
\text { Treatment: Administration of } 10 \mathrm{mM} / \mathrm{kg} / \text { day CAPE for } 15 \text { days } \\
\text { after the periodontitis induction (i.p. administration) } \\
\text { Negative control: Saline injection into the vestibular gingival site } \\
\text { and daily saline i.p. injection } \\
\text { Positive control: n.a. }\end{array}$ & $\begin{array}{l}\downarrow \text { RANKL-positive osteoclasts, IL-I } \beta \text {, OSI, alveolar bone loss } \\
\text { and histological analysis score with lesser inflammatory } \\
\text { reactions, ulcer and hyperemia compared with negative control } \\
\text { with diabetes and periodontitis }\end{array}$ \\
\hline
\end{tabular}

(Continued) 
Table I (Continued).

\begin{tabular}{|c|c|c|}
\hline Researcher & Study Design & Findings \\
\hline $\begin{array}{l}\text { Kizildag } \\
\text { et al. }{ }^{43}\end{array}$ & $\begin{array}{l}\text { Animals: } 30 \text { male Sprague Dawley rats (3-month old and weight } \\
220-250 \mathrm{~g} \text { ) } \\
\text { Mode of disease induction: Endotoxin-induced periodontitis by } \\
\text { injecting } 10 \mu \mathrm{L} \text { of LPS ( } 1 \mathrm{mg} / \mathrm{mL} \text { ) into the vestibular gingival sites } \\
\text { between the right first and second maxillary molars } \\
\text { Treatment: i.p. administration of } 10 \mathrm{mmol} / \mathrm{kg} / \text { day CAPE for } 28 \\
\text { days after the periodontitis induction } \\
\text { Negative control: Saline injection into the vestibular gingival site } \\
\text { and daily saline i.p. injection } \\
\text { Positive control: n.a. }\end{array}$ & $\begin{array}{l}\downarrow \text { LPS-upregulated RANKL-positive osteoclasts, IL-I } \beta \text { and } \\
\text { oxidative stress index levels (but not CTX-I) } \\
\downarrow \text { periodontitis-mediated bone } \\
\text { resorption, attachment loss and damage to the periodontal } \\
\text { ligament } \\
\uparrow \text { LPS-downregulated periodontal bone support (MPBS \& DPBS) }\end{array}$ \\
\hline $\begin{array}{l}\text { Kizildag } \\
\text { et al. }{ }^{44}\end{array}$ & $\begin{array}{l}\text { Animals: } 40 \text { male Sprague Dawley rats ( } 12 \text {-week old and weight } \\
\text { 250 g) } \\
\text { Mode of disease induction: A I } 2 \text { h-restraint procedure was } \\
\text { applied daily from I } 5 \text { days before LPS injection until I } 4 \text { days } \\
\text { after LPS injection to induce chronic stress. } \\
\text { A } 10 \mu \mathrm{L} \text { of LPS (I } \mathrm{mg} / \mathrm{mL} \text { ) was injected into the vestibular } \\
\text { gingival sites between the right first and second maxillary } \\
\text { molars to induce periodontitis. } \\
\text { Treatment: Administration of } 10 \mathrm{mmol} / \mathrm{kg} / \text { day CAPE for I } 4 \text { days } \\
\text { after the periodontitis induction (i.p. administration) } \\
\text { Negative control: Saline injection into the vestibular gingival site } \\
\text { and daily saline i.p. injection } \\
\text { Positive control: n.a. }\end{array}$ & $\begin{array}{l}\uparrow \text { periodontal bone support (MPBS and DPBS) and } \downarrow \text { RANKL- } \\
\text { positive osteoclasts, IL-I } \beta \text { and OSI levels, compared with } \\
\text { negative control with chronic stress and periodontitis }\end{array}$ \\
\hline
\end{tabular}

Abbreviations: $\uparrow$, increase or upregulate; $\downarrow$, decrease or downregulate; Akt, protein kinase B; AP-I, activator protein I; ALP, alkaline phosphatase; BMD, bone mineral density; BMMs, bone marrow macrophages; BMP, bone morphogenetic proteins; BV, bone volume; BV/TV, bone volume fraction; CA, caffeic acid; CADPE, caffeic acid 3,4-dihydroxy-phenethyl ester; CAIA, collagen antibody-induced arthritis; CAPE, caffeic acid phenethyl ester; COL-I, collagen type I; c-Src, cellular sarcoma tyrosine kinase; CTX-I, carboxyterminal collagen crosslinks Type-I; DMSO, dimethyl sulphoxide; DPBS, distal periodontal bone support; EMF, electromagnetic fields; ERKI/2, extracellular signal-regulated kinases I/2; ES/BS, eroded surface/bone surface; GSH, glutathione; GSM, global system for mobile communications; GPx, glutathione peroxidase; IL, interleukin; IкB $\alpha$, NF-кB inhibitor protein alpha; IKK, ІкB kinase; i.p, intraperitoneal; JNK, c-Jun N-terminal kinase; LPS, lipopolysaccharide; M-CSF, macrophage colonystimulating factor; MAPK, mitogen-activated protein kinase; MDA, malondialdehyde; MHz, megahertz; MPBS, mesial periodontal bone support; n.a., not available; NFAT, nuclear factor of activated T cells; NFATcl, nuclear factor of activated T-cells cytoplasmic I; NF-KB, nuclear factor kappa B; N.Oc/B.Pm, osteoclast number/bone perimeter; NoxI, nicotinamide adenine dinucleotide phosphate oxidase I; NS, not significant; OCL, osteoclast-like cells; Oc.S/BS, osteoclast surface/bone surface; OPG, osteoprotegerin; OSC, osteocalcin; OSCAR, osteoclast-associated receptor; OSI, oxidative stress index; OSX, osterix; OVX, ovariectomy; PMNLs, polymorphonuclear cells; Racl, Ras-related C3 botulinum toxin substrate I; RANKL, receptor activator of NF-KB ligand; RUNX2, Runt-related transcription; SOD, superoxide dismutase; STZ, streptozotocin; Tb.N, trabecular number; Tb.Sp, trabecular spacing; TGF $\beta$ I, transforming growth factor-beta I; TGF $\beta$-R, transforming growth factor-beta receptor; TNF $\alpha$, tumour necrosis factor-alpha; TRAF6, tumour necrosis factor receptor-associated factor 6; TRAP5b, tartrate-resistant acid phosphatase 5b; W, watts.

of compact bone in the tibia of OVX-induced osteoporotic rats as evidenced by negligible changes of bone mass, bone mineral mass, bone mass/body mass ratio and bone mineral mass/body mass ratio. ${ }^{52}$ On the other hand, Zych et al. reported that $\mathrm{CA}$ at a similar dose $(10 \mathrm{mg} / \mathrm{kg} / \mathrm{day}$; by stomach tube for 4 weeks) worsened the bone mechanical properties of healthy female Wistar Cmd:(WI)WU rats by decreasing the load of fracture at the femoral neck, decreasing the width of periosteal osteoid in the tibia and decreasing the width of the epiphysis and metaphysis trabecular in the femur compared with the negative control group. $^{49}$

CAPE is the most extensively studied caffeic acid derivative in animal studies. The beneficial effects on new bone formation and healing upon systemic administration of CAPE had been reported. ${ }^{46,47,53,57}$ Erdem et al. reported that a low dose of CAPE $(10 \mu \mathrm{mol} / \mathrm{kg}$; i.p. injection for 22 days) increased new bone formation and bone strength by increasing maximum torsional fracture momentum and degree of rigidity compared with negative control in rats that underwent unilateral femoral lengthening (osteotomy). ${ }^{53}$ Similarly, a 30-day i.p. injection of CAPE (10 $\mu \mathrm{mol} / \mathrm{kg} /$ day) also increased bone healing level in Sprague Dawley rats with cranial critical size bone defect. $^{57} \mathrm{~A}$ higher dose of CAPE (10 mmol/kg/day, i.p. for 20 days) also further promoted the RME procedure-induced new bone formation in midpalatal suture of male Sprague Dawley rats. ${ }^{47}$ Similarly, a longer treatment 


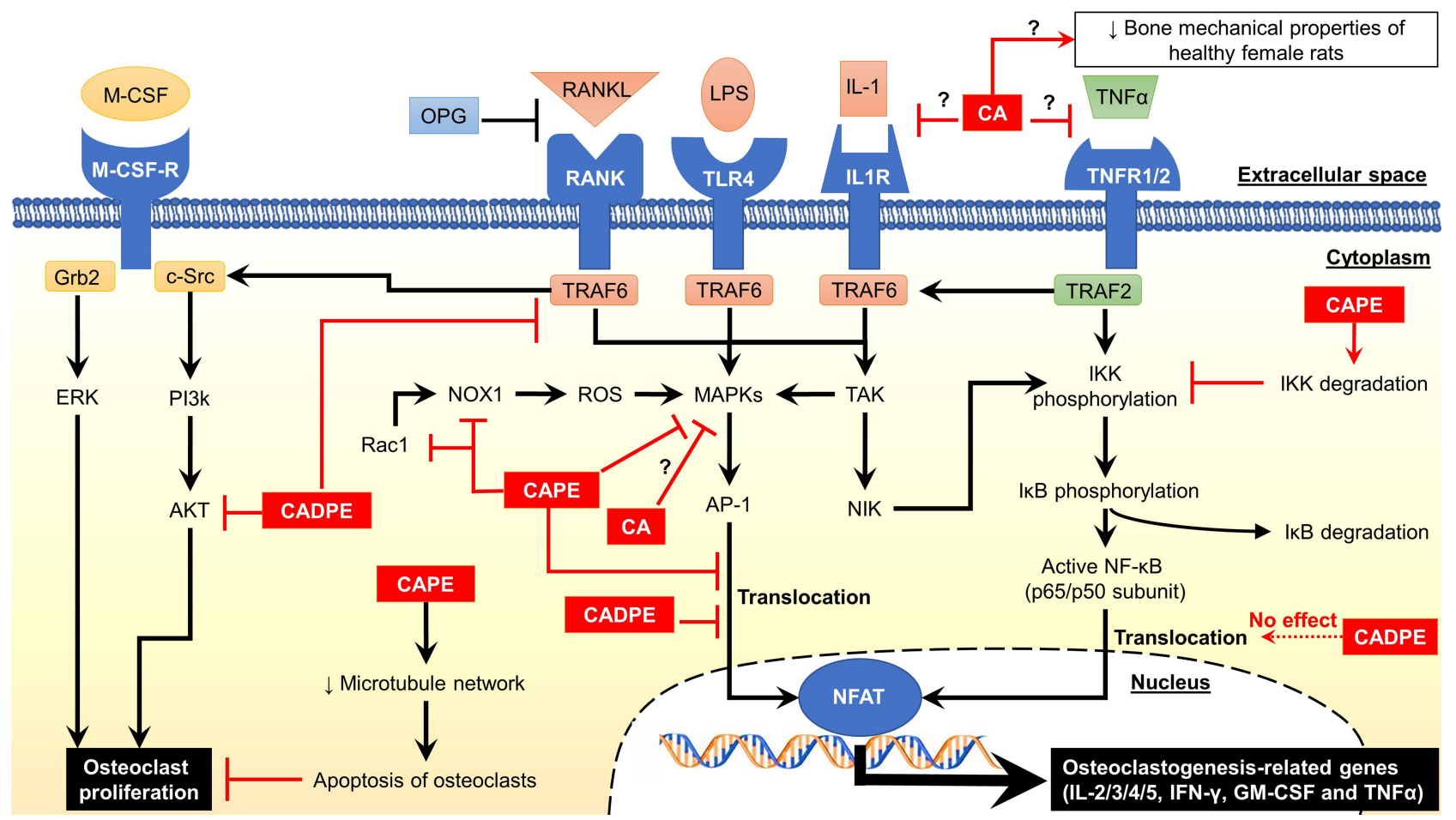

Figure 2 Mechanism of action of caffeic acid and its derivatives.

Abbreviations: $\downarrow$, decrease or downregulate; ?, unknown mechanism; Akt, protein kinase B; AP-I, activator protein I; CA, caffeic acid; CADPE; caffeic acid 3,4-dihydroxyphenethyl ester; CAPE, caffeic acid phenethyl ester; c-Src, cellular sarcoma tyrosine kinase; ERKI/2, extracellular signal-regulated kinases I/2; GM-CSF, granulocytemacrophage colony-stimulating factor; Grb2, growth factor receptor-bound protein 2; IFN- $\gamma$, interferon-gamma; IL, interleukin; ILIR, interleukin-I receptor; IאB, NF-KB inhibitor protein; IKK, IКB kinase; LPS, lipopolysaccharide; M-CSF, macrophage colony-stimulating factor; M-CSF-R, M-CSF receptor; MAPKs, mitogen-activated protein kinases; NFAT, nuclear factor of activated T cells; NF-KB, nuclear factor kappa B; NIK, MAPK kinase kinase I4; NoxI, nicotinamide adenine dinucleotide phosphate oxidase I; OPG, osteoprotegerin; PI3k, phosphoinositide 3-kinase; Racl, Ras-related C3 botulinum toxin substrate I; RANK, receptor activator of NF-KB; RANKL, receptor activator of NF-KB ligand; ROS, reactive oxygen species; TAK, MAPK kinase kinase 7; TLR4, Toll-like receptor 4; TNF $\alpha$, tumour necrosis factor-alpha; TNFRI/2, TNF receptor I/2; TRAF2, tumour necrosis factor receptor-associated factor 2; TRAF6; tumour necrosis factor receptor-associated factor 6.

period of CAPE $(10 \mathrm{mmol} / \mathrm{kg} /$ day; i.p. injection for 28 days) also significantly promoted bone healing by increasing the total new bone areas in surgical-induced calvarial defects of male Wistar rats compared with the negative control. ${ }^{46}$ However, localised administration of CAPE (28 days) on surgical-induced calvarial defects by pre-mixing 50 and $100 \mathrm{mmol} / \mathrm{kg}$ CAPE solutions with gelatin sponges did not significantly improve the new bone formation. ${ }^{46}$

Localised and systemic administration of CAPE was reported to be beneficial in reducing osteolysis and bone loss. ${ }^{35,42-45,50,54-56,58} \mathrm{Ha}$ et al. reported that collagen sponge implant impregnated with $250 \mu \mathrm{g}$ CAPE and RANKL could reduce osteoclastogenesis with significantly lesser TRAP-stained area in mouse calvariae compared with implants with RANKL only. ${ }^{35}$ Subcutaneous injection of CAPE $(1 \mathrm{mg} / \mathrm{kg} /$ day for 10 days $)$ reduced the polyethylene particle-induced calvarial osteolysis, surface bone resorption and TRAP-positive cells formation with an increase of bone volume (BV) on LPS-resistant $\mathrm{C} 3 \mathrm{H} /$
HEJ female mice. ${ }^{58}$ However, no significant changes were observed in carboxy-terminal cross-linked type 1 collagen (CTX-1) and osteoclast-associated receptor levels among untreated and CAPE-treated rats with calvarial osteolysis. $^{58}$

Similarly, Duan et al. reported that lower dose and frequency of CAPE injection $(0.5 \mathrm{mg} / \mathrm{kg}$ twice a week; i. p. injection for 4 weeks) also increased the BV and trabecular number (Tb.N) due to the decrease of bone osteoclast formation (evidenced by decreased osteoclast number/ bone perimeter) in OVX mice. ${ }^{55}$ Tolba et al. also reported that i.p. injection of CAPE (10 and $20 \mu \mathrm{mol} / \mathrm{kg}$ ) for 3 weeks increased femur weight and length in rats with dexamethasone-induced bone loss. ${ }^{56}$ The preservation of skeletal health in their study was associated with an improved antioxidant defence, such as higher levels of glutathione (GSH) and superoxide dismutase (SOD), and the reduction of malondialdehyde (MDA, lipid peroxidation product). ${ }^{56}$ This event led to an increase of 
osteoblastogenesis indicated by upregulation of RUNX-2 and ALP (osteoblast marker) levels ${ }^{56}$ On the other hand, decreased RANKL/osteoprotegerin (OPG) ratio was observed with CAPE treatment, indicating the suppression of osteoclastogenesis, which was further confirmed by lower acid phosphatase level and TRAP activity. ${ }^{56}$ In another study by Yildiz et al., CAPE (10 $\mu \mathrm{mol} / \mathrm{kg} / \mathrm{day}$; $i$. p. injection for 22 days) also increased the spine and femur BMD in rats with EMF-induced bone loss. ${ }^{50}$ Similarly, Cicek et al. reported a longer treatment of CAPE (10 $\mu \mathrm{mol} / \mathrm{kg} /$ day; i.p. injection for 28 days) also significantly improved the mechanical strength of cortical bone by increasing the breaking force, bending strength and total fracture energy in rats with EMF-induced bone loss compared with negative control. ${ }^{54}$

Additionally, a study by $\mathrm{Wu}$ et al. treated mice with an OVX-induced bone loss with a moderately high dose of CADPE (10 mg/kg; i.p. injection) every 2 days for 3 months. $^{38}$ Results showed that CADPE could increase the BV fraction (BV/TV) and Tb.N, as well as decreased trabecular spacing (Tb.Sp) compared with the negative control. $^{38}$ The improvement in the bone structure was contributed by reduced osteoclast number and eroded surface on the bone. ${ }^{38}$ Assessment of bone remodelling markers also revealed that serum TRAP5b and CTX-1 levels were reduced in CADPE-treated group compared with the negative control. ${ }^{38}$

On the other hand, CAPE was effective in reducing periodontitis-related bone loss and osteolysis. ${ }^{42-45} \mathrm{CAPE}$ (10 $\mu \mathrm{mol} / \mathrm{kg} /$ day, i.p. for 14 days) significantly reduced the subgingival ligature placement-induced periodontitismediated articular bone loss, histopathological features and severity of periodontal inflammation with lesser polymorphonuclear cells (PMNLs) infiltration in the junctional epithelium and connective tissues among Wistar albino rats. ${ }^{45}$ CAPE also suppressed the periodontitisupregulated interleukin (IL)-1 $\beta$, IL-6, IL-10, TNF $\alpha$, MDA levels and the percentage of gingival apoptosis with the parallel restoration of periodontitisdownregulated GSH and glutathione peroxidase (GPx). ${ }^{45}$ Administration of high-dose CAPE $(10 \mathrm{mmol} / \mathrm{kg} / \mathrm{day}$; i.p. for 15 days) in streptozotocin (STZ)-induced diabetic male Sprague Dawley rats reduced RANKL-positive osteoclast number, IL-1 $\beta$ levels, oxidative stress index (OSI), alveolar bone loss and histological analysis score in LPSinduced periodontitis. The treated rats also suffered lesser inflammatory reactions, ulcers and hyperemia. ${ }^{42}$ Similar changes of osteoclast number, IL-1 $\beta$ and OSI were observed in male Sprague Dawley rats with chronic stress and LPS-induced periodontitis treated with CAPE (10 $\mathrm{mmol} / \mathrm{kg} /$ day, i.p. for 14 days). ${ }^{44}$ In addition, CAPE also increased the mesial and distal periodontal bone supports (MPBS and DPBS) in these rats. ${ }^{44}$ The effects of CAPE were sustained with a longer treatment period of CAPE (10 mmol/ $\mathrm{kg} /$ day, i.p. for 28 days) on male Sprague Dawley rats with LPS-induced periodontitis. ${ }^{43}$

In contrast to the above findings, Williams et al. reported that subcutaneous injection of CAPE $(1 \mathrm{mg} / \mathrm{kg}$; at day 3, 7 and 10) did not reduce paw inflammation or bone loss in CAIA mice. ${ }^{51}$ Cartilage and bone degradation, as well as TRAP-positive cells on the bone surface and soft tissues, were still apparent in the supplemented CAIA group compared with the normal control. ${ }^{51}$

\section{Discussion}

This systematic review found that although $\mathrm{CA}$ and its derivatives is a potential anti-osteoporosis agent by suppressing the formation of osteoclasts and their bone resorption activity, it worsened bone mechanical properties in some cases. The anti-osteoclastogenesis action of CA and its derivatives was mediated by the antioxidant activities, which blocked RANKL-induced TRAF6/Akt and MAPK signalling, as well as $\mathrm{M}-\mathrm{CSF} / \mathrm{c}-\mathrm{Src}$ signalling. In animals, CA and its derivatives (mainly CAPE) prevented bone resorption in rodent calvariae when implanted in situ, facilitated the healing of bone defects, preserved bone structure and improved mechanical strength in osteoporosis models induced by OVX, dexamethasone, osteotomy, LPS-mediated periodontitis and EMF. However, CA did not alter bone resorption in OVX-induced osteoporotic rats and worsened the mechanical properties in normal rats. Additionally, CAPE did not suppress bone loss in rats with CAIA-induced bone loss.

Osteoblasts are bone-forming cells derived from bone marrow mesenchymal stem cells and are responsible for the synthesis, secretion and mineralisation of bone matrix. ${ }^{61}$ The expression of osteoblast markers was increased following CA or CAPE supplementation, an indication that $\mathrm{CA}$ and CAPE stimulated osteoblast proliferation, differentiation and maturation. ${ }^{40,56}$ Osteoblasts and osteocytes regulate the formation of osteoclasts through RANKL/OPG axis. Osteoblasts and osteocytes synthesise RANKL, which binds to RANK to activate the canonical pathway for osteoclastogenesis. They also secrete OPG, which is a decoy receptor for RANKL to suppress osteoclastogenesis. The production of RANKL is 
stimulated under conditions such as oestrogen deficiency ${ }^{62}$ and oxidative stress. ${ }^{63}$ Osteoclastogenesis can also be stimulated via a non-canonical pathway, for instance, through the binding of TNF $\alpha$ with TNF receptor I or II. $^{64}$ Glucocorticoids are potential modulators of RANKL/OPG axis, whereby dexamethasone is shown to downregulate OPG levels in osteoblasts. ${ }^{65}$ Tolba et al. showed that the RANKL/OPG level reduced in rats induced with dexamethasone with CAPE treatment. ${ }^{56}$ Other cellular studies showed that $\mathrm{CA}$ and its derivatives suppressed RANKL- and TNF $\alpha$-induced formation of OCLs from haematopoietic cells, ${ }^{35-39}$ indicating that CA and its derivatives suppressed both canonical and noncanonical osteoclastogenesis.

The complex formed by the binding of RANKL to RANK causes the recruitment of the adaptor molecule's tumour necrosis factor receptor-associated factors (TRAFs), including TRAF6. ${ }^{66}$ This event leads to the activation of several downstream signalling pathways, including c-Src/Akt/phosphatidylinositol 3-kinase and MAPKs (ERK/p38/JNK). CADPE was shown to suppress RANKL-induced activation of TRAF6 activation and the subsequent signalling pathways in multiple osteoclast progenitors, such as BMMs, ${ }^{38}$ RAW264.7 ${ }^{38}$ and RAW D cells. ${ }^{39}$ Sandra and Ketherin suggested that the downregulation of p38 is the key step of CA-mediated osteoclastogenesis. ${ }^{39}$ Upon activation, p38 initiates osteoclastogenesis by inducing NF- $\mathrm{KB}$ and NFATc1 expression. ${ }^{67,68}$ Inhibition of p38 MAPK reduces RANKL (canonical) and TNF $\alpha$-induced (non-canonical) osteoclast formation. ${ }^{69}$

The NF-kB pathway is another signalling pathway downstream of TRAFs critical for osteoclast differentiation and bone reabsorption activity. Upon activation, IKK (consisting of IKK $\alpha$, IKK $\beta$ and IKK $\gamma$ ) phosphorylates and degrades I $\mathrm{KB} \alpha$, which enables translocation of NF- $\kappa \mathrm{B}$ p 65 / p50 heterodimers into the nucleus to allow transcription of osteoclast-related genes. ${ }^{70}$ Kwon et al. demonstrated that the anti-osteoclastogenesis effects of CAPE were mediated via the degradation of total IKK $\beta$, thereby preventing the phosphorylation and degradation of $\mathrm{I} \kappa \mathrm{B} \alpha$ and subsequently suppresses the nuclear translation of $\mathrm{p} 65 .{ }^{37} \mathrm{On}$ the other hand, $\mathrm{Wu}$ et al. reported that CADPE did not affect phosphorylation or degradation of $\mathrm{I} \kappa \mathrm{B} \alpha$, as well as nuclear translocation, and DNA-binding activity of $\mathrm{p} 65 .^{38}$ This observation suggests that compared with CAPE, CADPE does not influence the NF- $\kappa B$ signalling pathway.
ROS are one of the important secondary signals in the early stages of osteoclast differentiation. ${ }^{71,72}$ These ROS are mainly produced as superoxide anions by Nox $1 .^{73}$ Blocking of Nox1 ameliorates ROS production and the downstream MAPKs (JNK, p38 and ERK) and NF-kB activation $^{74}$ and subsequently suppresses the osteoclast formation. ${ }^{71}$ The reduction of Nox 1 and Rac1 expression by CAPE is accompanied by RANKL-downstream signalling, denoting that anti-osteoclastogenesis effects of CAPE are dependent on suppression of Nox1-mediated superoxide anion production. Besides, dexamethasone has been reported to increase the expression of oxidative stressrelated genes in human osteoblasts. ${ }^{75}$ Tolba et al. showed that CAPE increased GSH and SOD but reduced MDA in the bone of the rats exposed to dexamethasone, indicating an improvement of redox status in the skeletal environment. ${ }^{56}$ Additionally, CAPE also reduced the OSI and bone loss with an improvement of bone support in rats with LPS-induced periodontitis.

NFATc1 is the master regulator of osteoclast-related gene expression, and it is activated by c-Fos and NF$\kappa B .{ }^{76} \mathrm{Ha}$ et al. observed that CAPE inhibited the recruitment of NF- $\mathrm{kB}$ to NFATc1 promoter, and the combined effect of NF- $\kappa$ B inhibition on c-Fos and NFATc1 may have caused CAPE to suppress osteoclastogenesis effectively. ${ }^{35}$ Holland et al. demonstrated a new fluorinated derivative of CAPE possesses potent anti-osteoclastogenic properties on RAW 264.7 cells by downregulating NFATc1 via suppression of c-Fos and NF-kB signalling pathways. ${ }^{77}$ Besides, this new fluorinated CAPE also exhibits improved stability with a 2-fold higher potency than CAPE. ${ }^{77}$ On the other hand, although CADPE did not alter NF- $\kappa B$ signalling, it still could suppress NFATc1 and other osteoclast-related markers, indicating other mechanisms of suppression could be involved, for instance, c-Src and MAPKs signalling pathways. ${ }^{38}$

Matrix metalloproteinases (MMPs), including gelatinases (MMP-2 and MMP-9) are examples of zincdependent extracellular matrix-degrading enzymes, which actively participate in bone resorption. ${ }^{78}$ MMPs are expressed as inactive proenzymes or zymogens that can be activated by several mediators including AP-1, NF- $\mathrm{KB}$, TNF $\alpha$ and TGF $\beta .^{78}$ Currently, there is no study conducted to investigate the inhibitory effects of CA and CAPE on osteoclastic MMPs activity and its subsequent linkage in bone resorption; interestingly, CA and CAPE were reported to inhibit MMP-9 activity in human hepatocellular carcinoma HEP3B cells. ${ }^{79,80}$ This observation renders 
an interesting research gap in osteoclastic MMP inhibition upon $\mathrm{CA}$ and its derivatives treatment.

Suppression of osteoclastogenesis by CA or its derivatives have significant therapeutic potential against bone disorders induced by excessive bone resorption. Bone loss after osteotomy is a rapid process that affects both fractured and unfractured bone and may be incompletely reversible. ${ }^{81}$ CAPE was reported to improve bone formation and mechanical strength of bone in osteotomy. ${ }^{53}$ Exposure to EMF radiation caused by high-voltage transmission lines and transformers could affect bone health through decreased BMD, serum calcium and ALP level leading to the increase of bone resorption. ${ }^{82}$ CAPE increased the spine and femur BMD levels ${ }^{50}$ and increased mechanical strength of bones ${ }^{54}$ in rats exposed to EMF radiation. Total hip arthroplasty without cement often caused osteolysis induced by polyethylene particles. ${ }^{83}$ CAPE was shown by Zawawi et al. to prevent calvarial bone resorption in a murine polyethylene particle-induced osteolysis model. ${ }^{58}$ Therefore, biomaterials impregnated with $\mathrm{CA}$ or its derivatives could be adopted to prevent osteolysis in the arthroplasty procedure. CA has been incorporated in chitosan/(3-chloropropyl) trimethoxysilane scaffold for hard-tissue engineering applications and this adopted material exhibits antibacterial and anticancer effects. ${ }^{84}$ Ucan et al. observed that CAPE increased cranial bone healing in rats with critical size bone defect, suggesting that it could be administered systematically or locally to treat bone fracture/defect healing. ${ }^{57}$

Similarly, CAPE also effectively reduced the articular bone loss, inflammatory cytokines production and oxidative stress in rats with LPS-mediated periodontitis. Additionally, $\mathrm{Wu}$ et al. $^{38}$ and Duan et al. ${ }^{55}$ demonstrated that CADPE prevented the ovariectomy-induced bone loss by suppressing osteoclast activity in a mouse model, while Folwarczna et al. showed increased width of trabecular metaphysis in the femur of OVX rats. ${ }^{48}$ Similarly, Tolba et al. showed improved bone formation and skeletal health in rats with dexamethasone-induced bone loss upon receiving CAPE. $^{56}$ Additionally, $\mathrm{CA}$ and its derivatives may be involved in oestrogen production and signalling. Zych et al. reported that an oral administration of CA (10 mg/kg/day for 4 weeks) significantly restored the serum oestradiol levels in OVX rats. ${ }^{85}$ Interestingly, $\mathrm{CA}$ at 10 and $100 \mu \mathrm{M}$ did not cause any alteration in calcium content in the femoral-diaphyseal and metaphyseal ex vivo culture, suggesting its bone-protecting effect may not involve calcium metabolism and regulation. ${ }^{86}$
Additionally, CAPE was reported as a selective human oestrogen receptor $\beta$ agonist with the $\mathrm{EC}_{50}$ value of 3.72 $\mu \mathrm{M}$ in oestrogen-responsive element transcription. ${ }^{87}$ A recent in silico study by Zhao et al. suggested potential osteoimmunological effects of CAPE, which may explain its biological activities on both immune and skeletal systems. $^{88}$ However, the findings from this modelling study requires further validation through in vitro and in vivo models. As oestrogen deficiency due to menopause and glucocorticoids present the most significant cause of primary and secondary osteoporosis globally, CA and its derivatives have the potential to be used as an adjuvant therapy to existing osteoporosis management strategies. The mechanisms of action of $\mathrm{CA}$ and its derivatives in osteoclastogenesis have been summarized in Figure 2.

Regardless of the positive effects of CA on bone status, some studies have reported negative effects associated with supplementation of CA and its derivatives. CA supplementation did not affect the bone resorption ${ }^{52}$ and reduced transverse growth of endosteal in femur ${ }^{48}$ of rats with OVX-induced osteoporosis. In normal rats, CA supplementation even negatively affected their bone mechanical properties. ${ }^{49}$ Moreover, CAPE supplementation has been reported to stimulate the synthesis of $\mathrm{PGE}_{2}{ }^{89}$ which mediates osteoclastogenesis through RANKL stimulation and activation of the NF- $\kappa$ B pathway. ${ }^{90}$ This event will eventually increase TRAP-positive OCLs. Similarly, Williams et al. showed that CAPE did not suppress osteoclastogenesis in rats with CAIA. ${ }^{51}$

In term of safety, the International Agency for Cancer Research classifies CA as Class 2B (possibly carcinogenic to humans), ${ }^{91}$ and it was reported to induce renal tubular cell hyperplasia, forestomach hyperplasia, renal cell adenoma and forestomach cancer in rodents. ${ }^{92-94} \mathrm{CA}$ has been reported to be non-mutagenic and nonclastogenic. $^{91}$ Therefore, its carcinogenicity may involve epigenetic modification. Human toxicity and carcinogenicity of $\mathrm{CA}$ and its derivatives remain unknown. CA also showed anti-implantation activity in pregnant mice at a median effective dose of $4.26 \mathrm{mg} / \mathrm{kg} /$ day. ${ }^{95}$ Similarly, $5 \mathrm{mg} / \mathrm{kg} /$ day and $150 \mathrm{mg} / \mathrm{kg}$ of CA in mice demonstrated anti-implantation activity in early pregnancy. ${ }^{96}$ On the other hand, $0.15 \mathrm{mg} / \mathrm{kg} /$ day, $5 \mathrm{mg} / \mathrm{kg} /$ day and $150 \mathrm{mg} /$ $\mathrm{kg} /$ day of CA for 21 days in mice showed no maternal toxicity, foetal teratogenesis or post-natal effects on pup development and mortality. ${ }^{96}$ The same experiment stated that the no-observed-adverse-effect level of CA for pregnant female mice was $0.15 \mathrm{mg} / \mathrm{kg} / \mathrm{day} .{ }^{96}$ Therefore, high- 
dose CA should be cautioned in humans, especially pregnant women.

Several common limitations can be identified from the studies reviewed. Most studies did not adopt a positive control to compare against the anti-osteoclastogenesis or anti-osteoporosis effect of CA. Therefore, the therapeutic effects of CA and currently available anti-resorptive therapy cannot be compared. Although osteoblastogenesis and bone formation are also important in bone remodelling, evidence of CA on these processes is limited in the literature. The actions of CA in humans cannot be confirmed due to the lack of human clinical trials. These aspects can be improved in future studies.

The current review also has several limitations. We only considered articles indexed by PubMed, Scopus, Cochrane Library and Web of Science; therefore, nonindexed articles could be overlooked. We only selected articles studying $\mathrm{CA}$ or its derivatives as a single compound to understand its mechanism of action properly without other interference, but not a mixture of compounds or natural products rich in $\mathrm{CA}$. CA are present in foods, and interaction with other compounds in the food matrix might alter its absorption, bioavailability and action on the target tissue. Moreover, the heterogeneous findings of $\mathrm{CA}$ in bone loss reduction upon oral administration further emphasise these possibilities.

\section{Conclusions}

The current preclinical evidence agrees that CA and its derivatives exert promising skeletal protective effects by inhibiting osteoclastogenesis and bone resorption, but literature on bone formation is limited. Notwithstanding that, the skeletal effects of CA and its derivatives in models of normal bone health should be investigated because the limited studies available show undesirable effects. Human clinical trials to validate the skeletal effects of CA are lacking. Therefore, a well-planned clinical trial should be conducted to confirm the potential of CA as an antiresorptive agent. This information is critical for CA and its derivatives to be incorporated as part of the strategies to prevent bone loss.

\section{Acknowledgments}

The researchers are funded by Universiti Kebangsaan Malaysia through Research University Grant (GUP-2020021). S.O.E. and K.L.P. are post-doctoral researchers funded by Universiti Kebangsaan Malaysia through FPR1 and RGA-1 grants.

\section{Disclosure}

The authors report no conflicts of interest in this work.

\section{References}

1. Katsimbri P. The biology of normal bone remodelling. Eur J Cancer Care (Engl). 2017;26(6):e12740. doi:10.1111/ecc.12740

2. Xiao W, Wang Y, Pacios S, et al. Cellular and molecular aspects of bone remodeling. In: Kantarci A, editor. Tooth Movement. Vol. 18. Basel: Karger; 2015:9-16.

3. Andersen TL, Sondergaard TE, Skorzynska KE, et al. A physical mechanism for coupling bone resorption and formation in adult human bone. Am J Pathol. 2009;174(1):239-247. doi:10.2353/ ajpath.2009.080627

4. Bonewald LF, Johnson ML. Osteocytes, mechanosensing and Wnt signaling. Bone. 2008;42(4):606-615. doi:10.1016/j. bone.2007.12.224

5. Jiao H, Xiao E, Graves DT. Diabetes and its effect on bone and fracture healing. Curr Osteoporos Rep. 2015;13(5):327-335. doi:10.1007/s11914-015-0286-8

6. Lean JM, Jagger CJ, Kirstein B, et al. Hydrogen peroxide is essential for estrogen-deficiency bone loss and osteoclast formation. Endocrinology. 2005;146(2):728-735. doi:10.1210/en.2004-1021

7. Huh YJ, Kim JM, Kim H, et al. Regulation of osteoclast differentiation by the redox-dependent modulation of nuclear import of transcription factors. Cell Death Differ. 2006;13(7):1138-1146. doi:10.1038/sj.cdd. 4401793

8. Fontani F, Marcucci G, Iantomasi T, et al. Glutathione, $\mathrm{N}$-acetylcysteine and lipoic acid down-regulate starvation-induced apoptosis, RANKL/OPG ratio and sclerostin in osteocytes: involvement of JNK and ERK1/2 signalling. Calcif Tissue Int. 2015;96 (4):335-346. doi:10.1007/s00223-015-9961-0

9. Bonewald LF. The amazing osteocyte. J Bone Miner Res. 2011;26 (2):229-238. doi:10.1002/jbmr.320

10. Jilka RL, Noble B, Weinstein RS. Osteocyte apoptosis. Bone. 2013;54(2):264-271. doi:10.1016/j.bone.2012.11.038

11. Marathe N, Rangaswami H, Zhuang S, et al. Pro-survival effects of $17 \beta$-estradiol on osteocytes are mediated by nitric oxide/CGMP via differential actions of CGMP-dependent protein kinases I and II. J Biol Chem. 2012;287(2):978-988. doi:10.1074/jbc.M111.294959

12. Soares DG, Andreazza AC, Salvador M. Avaliação de compostos com atividade antioxidante em células da levedura saccharomyces cerevisiae. Rev Bras Cienc Farm. 2005;41:95-100. doi:10.1590/ S1516-93322005000100011

13. Romagnoli C, Marcucci G, Favilli F, et al. Role of GSH/GSSG redox couple in osteogenic activity and osteoclastogenic markers of human osteoblast-like Saos-2 cells. FEBS J. 2013;280(3):867-879.

14. Banfi G, Iorio EL, Corsi MM. Oxidative stress, free radicals and bone remodeling. Clin Chem Lab Med. 2008;46(11):1550-1555. doi:10.1515/CCLM.2008.302

15. Jun JH, Lee S-H, Kwak HB, et al. N-acetylcysteine stimulates osteoblastic differentiation of mouse calvarial cells. $J$ Cell Biochem. 2008;103(4):1246-1255. doi:10.1002/jcb.21508

16. Sendur OF, Turan Y, Tastaban E, et al. Antioxidant status in patients with osteoporosis: a controlled study. Joint Bone Spine. 2009;76 (5):514-518. doi:10.1016/j.jbspin.2009.02.005

17. Almeida M, Han L, Martin-Millan M, et al. Skeletal involution by age-associated oxidative stress and its acceleration by loss of sex steroids. J Biol Chem. 2007;282(37):27285-27297. doi:10.1074/jbc. M702810200

18. Maggio D, Barabani M, Pierandrei M, et al. Marked decrease in plasma antioxidants in aged osteoporotic women: results of a cross-sectional study. $J$ Clin Endocrinol Metab. 2003;88 (4):1523-1527. doi:10.1210/jc.2002-021496 
19. Lean JM, Davies JT, Fuller K, et al. A crucial role for thiol antioxidants in estrogen-deficiency bone loss. J Clin Invest. 2003;112 (6):915-923. doi:10.1172/JCI200318859

20. Polat B, Halici Z, Cadirci E, et al. The effect of alpha-lipoic acid in ovariectomy and inflammation-mediated osteoporosis on the skeletal status of rat bone. Eur J Pharmacol. 2013;718(1-3):469-474. doi:10.1016/j.ejphar.2013.07.033

21. Mohamad S, Shuid AN, Mohamed N, et al. The effects of alpha-tocopherol supplementation on fracture healing in a postmenopausal osteoporotic rat model. Clinics (Sao Paulo). 2012;67:1077-1085. doi:10.6061/clinics/2012(09)16

22. Hall SL, Greendale GA. The relation of dietary vitamin C intake to bone mineral density: results from the pepi study. Calcif Tissue Int 1998;63(3):183-189. doi:10.1007/s002239900512

23. Sanders KM, Kotowicz MA, Nicholson GC. Potential role of the antioxidant $\mathrm{N}$-acetylcysteine in slowing bone resorption in early post-menopausal women: a pilot study. Transl Res. 2007;150:215. doi:10.1016/j.trs1.2007.03.012

24. Morton DJ, Barrett-Connor EL, Schneider DL. Vitamin c supplement use and bone mineral density in postmenopausal women. $J$ Bone Miner Res. 2001;16(1):135-140. doi:10.1359/jbmr.2001.16.1.135

25. Mainini G, Rotondi M, Di Nola K, et al. Oral supplementation with antioxidant agents containing alpha lipoic acid: effects on postmenopausal bone mass. Clin Exp Obstet Gynecol. 2012;39(4):489-493.

26. Clifford MN. Chlorogenic acids and other cinnamates - nature, occurrence, dietary burden, absorption and metabolism. J Sci Food Agric. 2000;80(7):1033-1043. doi:10.1002/(SICI)1097-0010(20000515)80:7<1033::AID-JSFA595>3.0.CO;2-T

27. Espindola KMM, Ferreira RG, Narvaez LEM, et al. Chemical and pharmacological aspects of caffeic acid and its activity in hepatocarcinoma. Front Oncol. 2019;9:541. doi:10.3389/ fonc. 2019.00541

28. Magnani C, Isaac VLB, Correa MA, et al. Caffeic acid: a review of its potential use in medications and cosmetics. Anal Methods. 2014;6 (10):3203-3210. doi:10.1039/C3AY41807C

29. Armutcu F, Akyol S, Ustunsoy S, et al. Therapeutic potential of caffeic acid phenethyl ester and its anti-inflammatory and immunomodulatory effects (review). Exp Ther Med. 2015;9(5):1582-1588. doi:10.3892/etm.2015.2346

30. Nardini M, D'Aquino M, Tomassi G, et al. Inhibition of human low-density lipoprotein oxidation by caffeic acid and other hydroxycinnamic acid derivatives. Free Radic Biol Med. 1995;19 (5):541-552. doi:10.1016/0891-5849(95)00052-Y

31. Laranjinha $\mathrm{J}$, Vierira $\mathrm{O}$, Almeida $\mathrm{L}$, et al. Inhibition of metmyoglobin $/ \mathrm{H}_{2} \mathrm{O}_{2}$-dependent low density lipoprotein lipid peroxidation by naturally occurring phenolic acids. Biochem Pharmacol. 1996;51(4):395-402. doi:10.1016/0006-2952(95)02171-X

32. Meyer AS, Donovan JL, Pearson DA, et al. Fruit hydroxycinnamic acids inhibit human low-density lipoprotein oxidation in vitro. J Agric Food Chem. 1998;46(5):1783-1787.

33. Fukumoto LR, Mazza G. Assessing antioxidant and prooxidant activities of phenolic compounds. J Agric Food Chem. 2000;48 (8):3597-3604. doi:10.1021/jf000220w

34. Moher D, Liberati A, Tetzlaff J, et al. Preferred reporting items for systematic reviews and meta-analyses: the prisma statement. PLoS Med. 2009;6(7):e1000097. doi:10.1371/journal.pmed.1000097

35. Ha J, Choi H-S, Lee Y, et al. Caffeic acid phenethyl ester inhibits osteoclastogenesis by suppressing NF kappaB and downregulating NFATc1 and c-Fos. Int Immunopharmacol. 2009;9(6):774-780. doi:10.1016/j.intimp.2009.03.001

36. Ang ES, Pavlos NJ, Chai LY, et al. Caffeic acid phenethyl ester, an active component of honeybee propolis attenuates osteoclastogenesis and bone resorption via the suppression of RANKL-induced NF-kappaB and NFAT activity. $J$ Cell Physiol. 2009;221 (3):642-649. doi:10.1002/jcp.21898
37. Kwon YB, Wang FF, Jang HD. Anti-osteoclastic effect of caffeic acid phenethyl ester in murine macrophages depends upon the suppression of superoxide anion production through the prevention of an active-nox1 complex formation. J Nutr Biochem. 2018;58:158-168. doi:10.1016/j.jnutbio.2018.03.023

38. Wu X, Li Z, Yang Z, et al. Caffeic acid 3,4-dihydroxy-phenethyl ester suppresses receptor activator of NF- $\mathrm{KB}$ ligand-induced osteoclastogenesis and prevents ovariectomy-induced bone loss through inhibition of mitogen-activated protein kinase/activator protein 1 and $\mathrm{Ca}^{2+}-$ nuclear factor of activated T-cells cytoplasmic 1 signaling pathways. J Bone Miner Res. 2012;27(6):1298-1308. doi:10.1002/jbmr.1576

39. Sandra F, Ketherin K. Caffeic acid inhibits RANKL and TNF- $\alpha$ induced phosphorylation of p38 mitogen-activated protein kinase in RAW-D cells. Indones Biomed J. 2018;10(2):140-143. doi:10.18585/ inabj.v10i2.437

40. Melguizo-Rodríguez L, Manzano-Moreno FJ, Illescas-Montes R, et al. Bone protective effect of extra-virgin olive oil phenolic compounds by modulating osteoblast gene expression. Nutrients. 2019;11 (8):1722. doi:10.3390/nu11081722

41. Sandra F, Kukita T, Tang QY, et al. Cafeic acid inhibits NFкB activation of osteoclastogenesis signaling pathway. Indones Biomed J. 2011;3(3):216-222. doi:10.18585/inabj.v3i3.153

42. Kızıldağ A, Arabacı T, Albayrak M, et al. A biochemical and immunohistochemical study of the effects of caffeic acid phenethyl ester on alveolar bone loss and oxidative stress in diabetic rats with experimental periodontitis. Biotech Histochem. 2020;95(6):456-463. doi:10.1080/10520295.2020.1718756

43. Kızıldağ A, Arabacı T, Albayrak M, et al. Therapeutic effects of caffeic acid phenethyl ester on alveolar bone loss in rats with endotoxin-induced periodontitis. J Dent Sci. 2019;14(4):339-345. doi:10.1016/j.jds.2019.03.011

44. Kızıldağ A, Arabacı T, Albayrak M, et al. Evaluation of caffeic acid phenethyl ester administration in chronically stressed rats with experimental periodontitis. Cumhur Dent J. 2019;22(1):114-120.

45. Yiğit U, Kırzıoğlu FY, Uğuz AC, et al. Is caffeic acid phenethyl ester more protective than doxycycline in experimental periodontitis? Arch Oral Biol. 2017;81:61-68. doi:10.1016/j.archoralbio.2017.04.017

46. Kazancioglu HO, Bereket MC, Ezirganli S, et al. Effects of caffeic acid phenethyl ester on wound healing in calvarial defects. Acta Odontol Scand. 2015;73(1):21-27. doi:10.3109/ 00016357.2014 .942876

47. Kazancioglu HO, Aksakalli S, Ezirganli S, et al. Effect of caffeic acid phenethyl ester on bone formation in the expanded inter-premaxillary suture. Drug Des Devel Ther. 2015;9:6483-6488. doi:10.2147/ DDDT.S97797

48. Folwarczna J, Pytlik M, Zych M, et al. Effects of caffeic and chlorogenic acids on the rat skeletal system. Eur Rev Med Pharmacol Sci. 2015;19(4):682-693.

49. Zych M, Folwarczna J, Pytlik M, et al. Administration of caffeic acid worsened bone mechanical properties in female rats. Planta Med. 2010;76(5):407-411. doi:10.1055/s-0029-1240603

50. Yildiz M, Cicek E, Cerci SS, et al. Influence of electromagnetic fields and protective effect of cape on bone mineral density in rats. Arch Med Res. 2006;37(7):818-821. doi:10.1016/j.arcmed.2006.03.006

51. Williams B, Tsangari E, Stansborough R, et al. Mixed effects of caffeic acid phenethyl ester (CAPE) on joint inflammation, bone loss and gastrointestinal inflammation in a murine model of collagen antibody-induced arthritis. Inflammopharmacology. 2017;25 (1):55-68. doi:10.1007/s10787-016-0306-z

52. Folwarczna J, Zych M, Burczyk J, et al. Effects of natural phenolic acids on the skeletal system of ovariectomized rats. Planta Med. 2009;75(15):1567-1572. doi:10.1055/s-0029-1185904

53. Erdem M, Gulabi D, Sen C, et al. Effects of caffeic acid phenethyl ester and melatonin on distraction osteogenesis: an experimental study. SpringerPlus. 2014;3:8. doi:10.1186/2193-1801-3-8 
54. Cicek E, Gokalp O, Varol R, et al. Influence of electromagnetic fields on bone fracture in rats: role of cape. Biomed Environ Sci. 2009;22 (2):157-160. doi:10.1016/S0895-3988(09)60039-8

55. Duan W, Wang Q, Li F, et al. Anti-catabolic effect of caffeic acid phenethyl ester, an active component of honeybee propolis on bone loss in ovariectomized mice: a micro-computed tomography study and histological analysis. Chin Med $J$ (Engl). 2014;127 (22):3932-3936.

56. Tolba MF, El-Serafi AT, Omar HA. Caffeic acid phenethyl ester protects against glucocorticoid-induced osteoporosis in vivo: impact on oxidative stress and RANKL/OPG signals. Toxicol Appl Pharmacol. 2017;324:26-35. doi:10.1016/j.taap.2017.03.021

57. Uçan MC, Koparal M, Ağaçayak S, et al. Influence of caffeic acid phenethyl ester on bone healing in a rat model. J Int Med Res. 2013;41(5):1648-1654. doi:10.1177/0300060513490613

58. Zawawi MS, Perilli E, Stansborough RL, et al. Caffeic acid phenethyl ester abrogates bone resorption in a murine calvarial model of polyethylene particle-induced osteolysis. Calcif Tissue Int. 2015;96 (6):565-574. doi:10.1007/s00223-015-9982-8

59. Renwick A. First-pass metabolism within the lumen of the gastrointestinal tract. Presystem Drug Eliminat. 2013;1:1.

60. Al Shoyaib A, Archie SR, Karamyan VT. Intraperitoneal route of drug administration: should it be used in experimental animal studies? Pharm Res. 2019;37(1):12. doi:10.1007/s11095-0192745-x

61. Fakhry M, Hamade E, Badran B, et al. Molecular mechanisms of mesenchymal stem cell differentiation towards osteoblasts. World J Stem Cells. 2013;5(4):136-148. doi:10.4252/wjsc.v5.i4.136

62. Beekman KM, Zwaagstra M, Veldhuis-Vlug AG, et al. Ovariectomy increases RANKL protein expression in bone marrow adipocytes of C3H/HEJ mice. Am J Physiol Endocrinol Metab. 2019;317(6): E1050-E1054. doi:10.1152/ajpendo.00142.2019

63. Mazière $\mathrm{C}$, Salle V, Gomila $\mathrm{C}$, et al. Oxidized low density lipoprotein enhanced RANKL expression in human osteoblast-like cells. Involvement of ERK, NFkappaB and NFAT. Biochim Biophys Acta Mol Basis Dis. 2013;1832(10):1756-1764. doi:10.1016/j. bbadis.2013.05.033

64. Feng W, Guo J, Li M. RANKL-independent modulation of osteoclastogenesis. J Oral Biosci. 2019;61(1):16-21. doi:10.1016/j. job.2019.01.001

65. Humphrey EL, Williams JHH, Davie MWJ, et al. Effects of dissociated glucocorticoids on OPG and RANKL in osteoblastic cells. Bone. 2006;38(5):652-661. doi:10.1016/j.bone.2005.10.004

66. Negishi-Koga T, Takayanagi H. $\mathrm{Ca}^{2+}$-NFATc1 signaling is an essential axis of osteoclast differentiation. Immunol Rev. 2009;231 (1):241-256. doi:10.1111/j.1600-065X.2009.00821.X

67. Cong Q, Jia H, Li P, et al. P38 $\alpha$ MAPK regulates proliferation and differentiation of osteoclast progenitors and bone remodeling in an aging-dependent manner. Sci Rep. 2017;7(1):45964. doi:10.1038/ srep45964

68. Kang J-H, Lim H, Jeong J-E, et al. Attenuation of RANKL-induced osteoclast formation via p38-mediated NFATc1 signaling pathways by extract of euphorbia lathyris 1. J Bone Metab. 2016;23 (4):207-214. doi:10.11005/jbm.2016.23.4.207

69. Thouverey C, Caverzasio J. Focus on the p38 MAPK signaling pathway in bone development and maintenance. Bonekey Rep. 2015;4:711. doi:10.1038/bonekey.2015.80

70. Boyce BF, Xiu Y, Li J, et al. NF- $\kappa$ B-mediated regulation of osteoclastogenesis. Endocrinol Metab (Seoul). 2015;30(1):35-44. doi:10.3803/EnM.2015.30.1.35

71. Lee NK, Choi YG, Baik JY, et al. A crucial role for reactive oxygen species in RANKL-induced osteoclast differentiation. Blood. 2005;106(3):852-859. doi:10.1182/blood-2004-09-3662

72. Thannickal VJ, Fanburg BL. Reactive oxygen species in cell signaling. Am J Physiol Lung Cell Mol Physiol. 2000;279(6): L1005-1028. doi:10.1152/ajplung.2000.279.6.L1005
73. Bedard K, Krause K-H. The Nox family of ROS-generating NADPH oxidases: physiology and pathophysiology. Physiol Rev. 2007;87 (1):245-313.

74. Sedeek M, Nasrallah R, Touyz RM, et al. NADPH oxidases, reactive oxygen species, and the kidney: friend and foe. Clin J Am Soc Nephrol. 2013;24(10):1512LP-1518. doi:10.1681/ASN.2012111112

75. Hurson CJ, Butler JS, Keating DT, et al. Gene expression analysis in human osteoblasts exposed to dexamethasone identifies altered developmental pathways as putative drivers of osteoporosis. BMC Musculoskelet Disord. 2007;8:12. doi:10.1186/1471-2474-8-12

76. Kim JH, Kim N. Regulation of NFATc1 in osteoclast differentiation. J Bone Metab. 2014;21(4):233-241. doi:10.11005/jbm.2014.21.4.233

77. Holland L, Mula RVR, Machiah D, et al. Fluorinated caffeic acid phenethyl ester: a novel anti-osteogenic molecule to attenuate excessive bone damage during autoimmune arthritis. FASEB J. 2016;30: lb451.

78. Liang H, Xu J, Xue M, et al. Matrix metalloproteinases in bone development and pathology: current knowledge and potential clinical utility. Metalloproteinases Med. 2016;3:93-102. doi:10.2147/MNM. S92187

79. Park WH, Kim SH, Kim CH. A new matrix metalloproteinase-9 inhibitor 3,4-dihydroxycinnamic acid (caffeic acid) from methanol extract of Euonymus alatus: isolation and structure determination. Toxicology. 2005;207(3):383-390. doi:10.1016/j.tox.2004.10.008

80. Jin UH, Chung TW, Kang SK, et al. Caffeic acid phenyl ester in propolis is a strong inhibitor of matrix metalloproteinase- 9 and invasion inhibitor: isolation and identification. Clin Chim Acta. 2005;362 (1-2):57-64. doi:10.1016/j.cccn.2005.05.009

81. Karlsson MK, Josefsson PO, Nordkvist A, et al. Bone loss following tibial osteotomy: a model for evaluating post-traumatic osteopenia. Osteoporos Int. 2000;11(3):261-264. doi:10.1007/s001980050290

82. Kunt H, Senturk I, Gonul Y, et al. Effects of electromagnetic radiation exposure on bone mineral density, thyroid, and oxidative stress index in electrical workers. Onco Targets Ther. 2016;9:745-754. doi:10.2147/OTT.S94374

83. Orishimo KF, Claus AM, Sychterz CJ, et al. Relationship between polyethylene wear and osteolysis in hips with a second-generation porous-coated cementless cup after seven years of follow-up. J Bone Joint Surg Am. 2003;85(6):1095-1099. doi:10.2106/00004623200306000-00018

84. Shiu J, Ho M-H, Yu S-H, et al. Preparation and characterization of caffeic acid grafted chitosan/CPTMS hybrid scaffolds. Carbohydr Polym. 2010;79(3):724-730. doi:10.1016/j.carbpol.2009.09.025

85. Zych M, Folwarczna J, Trzeciak HI. Natural phenolic acids may increase serum estradiol level in ovariectomized rats. Acta Biochimica Polonica. 2009;56(3):503-507. doi:10.18388/ abp.2009_2486

86. Lai YL, Yamaguchi M. Phytocomponent p-hydroxycinnamic acid stimulates bone formation and inhibits bone resorption in rat femoral tissues in vitro. Mol Cell Biochem. 2006;292(1-2):45-52. doi:10.1007/s11010-006-9175-x

87. Jung BI, Kim MS, Kim HA, et al. Caffeic acid phenethyl ester, a component of beehive propolis, is a novel selective estrogen receptor modulator. Phytother Res. 2010;24(2):295-300. doi:10.1002/ ptr.2966

88. Zhao YH, Pang XK, Nepal A, et al. Caffeic acid phenethyl ester effects: in silico study of its osteoimmunological mechanisms. Lett Drug Des Discov. 2020;17(5):556-562. doi:10.2174/ 1570180815666180803111902

89. Larki-Harchegani A, Hemmati AA, Arzi A, et al. Evaluation of the effects of caffeic acid phenethyl ester on prostaglandin E2 and two key cytokines involved in bleomycin-induced pulmonary fibrosis. Iran J Basic Med Sci. 2013;16(7):850-857.

90. Saegusa M, Murakami M, Nakatani Y, et al. Contribution of membrane-associated prostaglandin E2 synthase to bone resorption. J Cell Physiol. 2003;197(3):348-356. doi:10.1002/jcp.10356 
91. International Agency for Research on Cancer. Caffeic acid. IARC monographs on the evaluation of carcinogenic risks to humans. Some naturally occurring substances: food items and constituents, heterocyclic aromatic amines and mycotoxins. Vol 56. Lyon, France: lnternational Agency for Research on Cancer, World Health Organization; 1993:115-134.

92. Hagiwara A, Hirose M, Takahashi S, et al. Forestomach and kidney carcinogenicity of caffeic acid in $\mathrm{F} 344$ rats and $\mathrm{C} 57 \mathrm{BL} / 6 \mathrm{~N} \times \mathrm{C} 3 \mathrm{H} /$ HEN $F_{1}$ mice. Cancer Res. 1991;51:5655-5660.

93. Hirose M, Fukushima S, Shirai T, et al. Stomach carcinogenicity of caffeic acid, sesamol and catechol in rats and mice. Jpn J Cancer Res. 1990;81:207-212. doi:10.1111/j.1349-7006.1990.tb02550.x
94. Hirose M, Takesada Y, Tanaka H, et al. Carcinogenicity of antioxidants BHA, caffeic acid, sesamol, 4-methoxyphenol and catechol at low doses, either alone or in combination, and modulation of their effects in a rat medium-term multi-organ carcinogenesis model. Carcinogenesis. 1997;19(1):207-212. doi:10.1093/carcin/19.1.207

95. Zheng YQ, Xu FB, Zhou S, et al. [abortifacient activity of caffeic acid and its antiprogestational action in early pregnant mice]. Acta Pharmacol Sin. 1987;8(3):250-254.

96. Liu Y, Qiu S, Wang L, et al. Reproductive and developmental toxicity study of caffeic acid in mice. Food Chem Toxicol. 2019;123:106-112. doi:10.1016/j.fct.2018.10.040

\section{Publish your work in this journal}

Drug Design, Development and Therapy is an international, peerreviewed open-access journal that spans the spectrum of drug design and development through to clinical applications. Clinical outcomes, patient safety, and programs for the development and effective, safe, and sustained use of medicines are a feature of the journal, which has also been accepted for indexing on PubMed Central. The manuscript management system is completely online and includes a very quick and fair peer-review system, which is all easy to use. Visit http://www. dovepress.com/testimonials.php to read real quotes from published authors. 